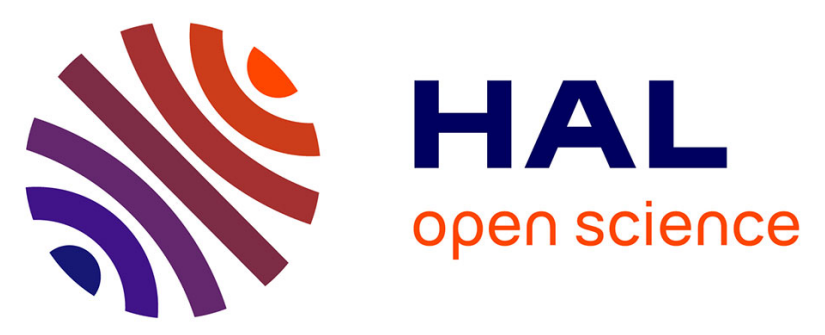

\title{
Distinct effects of human glioblastoma immunoregulatory molecules programmed cell death ligand-1 (PDL-1) and indoleamine 2,3-dioxygenase (IDO) on tumour-specific $\mathbf{T}$ cell functions.
}

Tony Avril, Stéphan Saikali, Elodie Vauléon, Anne Jary, Abderrahmane Hamlat, Marie de Tayrac, Jean Mosser, Véronique Quillien

\section{To cite this version:}

Tony Avril, Stéphan Saikali, Elodie Vauléon, Anne Jary, Abderrahmane Hamlat, et al.. Distinct effects of human glioblastoma immunoregulatory molecules programmed cell death ligand-1 (PDL-1) and indoleamine 2,3-dioxygenase (IDO) on tumour-specific T cell functions.. Journal of Neuroimmunology, 2010, 225 (1-2), pp.22-33. 10.1016/j.jneuroim.2010.04.003 . inserm-00486777

\section{HAL Id: inserm-00486777 https://www.hal.inserm.fr/inserm-00486777}

Submitted on 26 May 2010

HAL is a multi-disciplinary open access archive for the deposit and dissemination of scientific research documents, whether they are published or not. The documents may come from teaching and research institutions in France or abroad, or from public or private research centers.
L'archive ouverte pluridisciplinaire HAL, est destinée au dépôt et à la diffusion de documents scientifiques de niveau recherche, publiés ou non, émanant des établissements d'enseignement et de recherche français ou étrangers, des laboratoires publics ou privés. 


\section{Distinct effects of human glioblastoma immunoregulatory molecules programmed cell}

death ligand-1 (PDL-1) and indoleamine 2,3-dioxygenase (IDO) on tumour-specific T cell functions.

Tony AVRIL ${ }^{1}$, Stéphan SAIKALI ${ }^{2}$, Elodie VAULEON ${ }^{1,3}$, Anne JARY ${ }^{1}$, Abderrahmane HAMLAT $^{4}$, Marie DE TAYRAC ${ }^{3}$, Jean MOSSER $^{3}$, Véronique QUILLIEN ${ }^{1,3}$

Authors' affiliation:

${ }^{1}$ Département de Biologie, Centre Eugène Marquis, Rennes, France

${ }^{2}$ Département d'anatomopathologie, CHU Pontchaillou, Rennes, France

${ }^{3}$ UMR 6061 CNRS, Université de Rennes 1, IFR 140, Rennes, France

${ }^{4}$ Département de Neurochirurgie, CHU Ponchaillou, Rennes, France

Address for reprint requests:

Tony AVRIL, Département de Biologie, Centre Eugène Marquis, Rue de la bataille Flandres Dunkerque, CS44229, 35042 Rennes cedex, FRANCE. Phone: 33-299-253-190. Email: t.avril@,rennes.fnclcc.fr.

Grant support:

This work was supported by the "Ligue Contre le Cancer" Committee of Ille-et-Villaine and Maine-et-Loire, as well as the Institut National du Cancer (the 'From the core to the margin' glioma project), Région Bretagne (GIS Thérapie cellulaire, CPER 2000-2006), and the foundation "Aidez la recherche". 


\section{ABSTRACT}

Immunotherapy is a promising new treatment for patients suffering from glioma, in particular glioblastoma multiforme (GBM). However, tumour cells use different mechanisms to escape the immune responses induced by the treatment. As many other tumours, gliomas express or secrete several immunosuppressive molecules that regulate immune cell functions. In this study, we first analysed FasL, HLA-G, IDO, $P D L-1$ and TGF- $\beta 1,-\beta 2$ and $-\beta 3$ expression by transcriptomic microarray analysis in a series of 20 GBM samples and found respectively $15 \%, 60 \%, 85 \%, 30 \%, 70 \%, 80 \%$ and $35 \%$ of positive specimens. mRNA expression was then confirmed in 10 GBM primary cell lines and 2 immortalised cell lines U251 and U87MG. Furthermore, the protein expression of PDL-1, IDO activity and TGF- $\beta 2$ secretion were found on most of the untreated GBM primary cell lines. Remarkably, treatment with IFN- $\gamma$ increased the PDL-1 cell surface expression and the IDO activity, but reduced the TGF- $\beta 2$ secretion of GBM cell lines. We finally analysed the immunosuppressive effects of IDO, PDL-1 and TGF- $\beta 1-3$ by measuring IFN- $\gamma$ production and cell cytotoxicity activity of tumour antigen-specific T cells. PDL-1 partially affected the IFN- $\gamma$ production of antigenspecific $\mathrm{T}$ cells in response to GBM primary cell lines, and IDO inhibited lymphocyte proliferation induced by lectins. None of these molecules directly affected the $\mathrm{T}$ cell cytotoxicity function. Due to the functional role of PDL-1 and IDO molecules expressed by GBM cells, one could expect that blocking these molecules in the immunotherapy strategies would reinforce the efficiency of these treatments of GBM patients.

Key words: glioblastoma, immunotherapy, PDL-1, IDO, TGF- $\beta$, immunomodulation, $\mathrm{T}$ cells. 


\section{INTRODUCTION}

Glioblastoma multiforme, the most common primary brain tumour in adults, is an attractive target for novel therapies regarding its poor prognosis with standard treatment including total surgical resection, radiotherapy and adjuvant chemotherapy (Stupp et al., 2005). Indeed, despite intensive investigations for novel drugs, less than a third of patients survive more than two years (Stupp et al., 2009). Recurrence of GBM occurs most often within few months due to the re-growth of remaining tumour cells that are resistant to both radiotherapeutic and chemotherapeutic agents.

Cellular immunotherapy in gliomas, one of the promising new therapies, has shown convincing results in terms of induction of anti-tumour immune responses and prolonged survival compared with control groups receiving conventional chemotherapy and radiotherapy (Yamanaka, 2008). In particular, patients treated with dendritic cell vaccinations have demonstrated systemic antigen-specific cytotoxicity and intra-tumour infiltration of cytotoxic T cells (Yamanaka et al., 2003), (Kikuchi et al., 2004), (Yu et al., 2004), (Yamanaka et al., 2005). Liau et al. recently reported that $\mathrm{T}$ cell infiltration within the tumour was inversely correlated with the secretion of Transforming Growth Factor-beta 2 (TGF- $\beta 2$ ) by the glioma cells (Liau et al., 2005), highlighting the impact of the immunosuppressive properties of the tumour on the clinical efficiency of the treatment.

Local and systemic immune suppression has been involved in glioma progression (Weller and Fontana, 1995), (Walker et al., 2002). TGF- $\beta 2$, originally defined as the glioblastoma cell-derived T-cell suppressor factor, is a molecule that suppresses $\mathrm{T}$ cell growth and inhibits $\mathrm{T}$ cell activation and differentiation into effector cells (Gorelik and Flavell, 2002). Several other intra-cellular, membrane and soluble molecules such as FasL, HLA-G, PDL-1 (for Programmed cell Death Ligand-1, CD274), IDO (for Indoleamine2,3-DiOxygenase) and 
TGF- $\beta 1-3$ have been described as taking part in this phenomenon. The Fas ligand (FasL, CD178), which is a member of the TNF family, induces apoptosis in Fas (CD95)-expressing cells (Nagata and Golstein, 1995). Although FasL is expressed by immune cells as a cytotoxic molecule, it is also found on the surface of different types of cancer cells (Walker et al., 1997). FasL is expressed in human malignant glioma cells (Gratas et al., 1997). In addition, FasL expressed on glioma cell lines is active and induces the death of sensitive target cells such as Fas-transfected P815 cells (Saas et al., 1997), JURKAT T cell line (Weller et al., 1997) and $\mathrm{T}$ cell lines derived from infiltrating $\mathrm{T}$ lymphocytes from astrocytoma (Walker et al., 1997). HLA-G is a non-classical MHC class I molecule mainly expressed on placenta by the trophoblastic cells (Kovats et al., 1990). Although HLA-G mRNA expression has also been found in tumour cells such as melanoma and leukaemia cells, its protein expression is still controversial because of the heterogeneity of the results observed in the different studies (Bainbridge et al., 2001), (Chang and Ferrone, 2003). HLA-G can interact directly or indirectly (via the HLA-E molecule) with inhibitory receptors expressed on cytotoxic lymphocytes, which induces the abrogation of effector cell activation (Carosella et al., 2008). Wiendl et al. describe the expression of HLA-G in brain tumour tissues and glioma cell lines, and demonstrate that cytotoxicity, proliferation and $\mathrm{T}$ cell priming of alloreactive $\mathrm{PBMC}$ are inhibited by HLA-G (Wiendl et al., 2002). PDL-1 belongs to the B7 family, and is expressed on antigen presenting cells (Greenwald et al, 2005). Engagement of its receptor PD-1 inhibits $\mathrm{T}$ cell functions such as proliferation, cytokine production and cytotoxicity, and promotes apoptosis (Freeman et al., 2000), (Dong et al., 2002). PDL-1 has been observed on glioma and astrocytoma cell lines, and reduces IFN- $\gamma$ production of allogenic T cells (Wintterle et al., 2003), (Wilmotte et al., 2005). Finally, IDO is an intracellular enzyme that degrades tryptophan along the kynurenin pathway. IDO activity is essential in mouse placenta for preventing the rejection of allogenic fetuses (Munn et al., 1998). Its activity suppresses T cell 
activation and proliferation (Munn et al., 1999). IDO expression has also been described in cancer of different origins (Munn and Mellor, 2007), (Katz et al., 2008), including gliomas (Uyttenhove et al., 2003) and malignant glioma cell lines (Grant and Kapoor, 2003), (Miyazaki et al., 2009), in which both IDO expression and activity have recently been reported. To our knowledge, the effect of glioma cell IDO activity on T cell functions has not been investigated.

While the expression of FasL, HLA-G, PDL-1, IDO and TGF- $\beta 1-3$ molecules has been reported in glioma cells, their role in modulating GBM-specific T cell effector functions is not fully understood. This is particularly relevant with regard to cellular immunotherapy, whereby tumour-specific T cells would be generated to specifically kill GBM cells. In this study, we first describe the expression pattern of FasL, HLA-G, PDL-1, IDO and TGF- $\beta 1-3$ in a series of 20 GBM specimens using data derived from our previous transcriptomic analysis (de Tayrac et al., 2009). The mRNA expression of these molecules is then analysed in 10 GBM primary cell lines, as well as the immortalised cell lines U251 and U87MG. We then focus on the immunosuppressive effects of PDL-1, IDO and TGF- $\beta 1-3$ on GBM-specific CD8+ T cell effector functions, i.e. IFN- $\gamma$ secretion and cell cytotoxicity in response to GBM primary cell lines. We show that none of these molecules have a direct effect on cell cytotoxicity functions, but we provide evidence that PDL-1 affects GBM-specific CD8+ T cell IFN- $\gamma$ secretion in response to the tumour, and that GBM expresses functional IDO that inhibits the lectin-induced proliferation of lymphocytes. 


\section{MATERIALS AND METHODS}

Reagents and antibodies.

All reagents not specified below were purchased from Sigma-Aldrich (St Quentin Fallavier, France). Antibodies against CD3, CD8, HLA-ABC and PDL-1 were obtained from BD Biosciences (Le Pont de Claix, France); Melan-A/HLA-A2 tetramers from Beckman Coulter (Marseille, France); anti-EGFRvIII antibody from Skybio (Bedfordshire, United Kingdom); anti-IDO antibody from Millipore (St Quentin Fallavier, France); anti-IL13R $\alpha 2$ antibody from Diaclone (Besançon, France); anti-gp100 and anti-vimentin antibodies from DakoCytomation (Trappes, France); anti-HLA-G from Abcam (Paris, France); purified anti-PDL-1 from Clinisciences (Montrouge, France).

Tumour samples and cell culture.

GBM samples were obtained after informed consent of patients treated at the department of neurosurgery (Rennes University Hospital) in accordance with the local ethical committee. Tumours included in this study were diagnosed histologically as GBM or astrocytoma grade IV according to the WHO criteria.

GBM primary cell lines were obtained from GBM samples. After mechanical dissociation of tumour tissues samples, cells were grown in Dulbecco's Modification of Eagle's Medium (DMEM, Lonza, Verviers, Belgium) supplemented with 10\% fetal calf serum (FCS) (Lonza) for 24 hours at $37^{\circ} \mathrm{C}$ in a humid atmosphere of $5 \% \mathrm{CO}_{2}$. Unattached cells were then removed the day after. When confluence was achieved, cells were trypsinised, washed in PBS and used between the $10^{\text {th }}$ to $20^{\text {th }}$ passage for the experiments. Human trophoblastic cell line JEG-3 and glioblastoma cell lines U251 and U87MG were kindly provided by L. Amiot (Rennes, 
France), V. Catros (Rennes) and A. Clavreul (Angers, France), respectively. All the immortalised cell lines were cultured in DMEM 10\% FCS.

mRNA preparation, Reverse Transcriptase (RT)-PCR and electrophoresis.

Total RNA extraction was performed using the Rneasy Mini kit from Qiagen (Courtaboeuf, France) according to the manufacturer's recommendations. RNA concentrations were determined by optical density at $260 \mathrm{~nm}$, and RNA samples were stored at $-80^{\circ} \mathrm{C}$ until analysis. cDNA was prepared from $2 \mu \mathrm{g}$ purified RNA (First Strand cDNA Synthesis kit, Amersham Biosciences, Saclay, France) and 10-fold diluted before use. cDNA were amplified with a Taq polymerase and specific primers for human $\beta$-actin, FasL, HLA-G, IDO, PDL-1 and TGF- $\beta 1-3$ (MWG Biotech, Ebersberg, Germany) (Table 1). PCR was performed with a thermal cycler (RoboCycler Gradient 40, Stratagene, Amsterdam, Netherlands). After amplification, $25 \mu 1$ from each PCR product were electrophoresed on $2 \%$ agarose gel, and an amplified band was detected by ethidium bromide staining. The $100 \mathrm{bp}$ DNA ladder was used as molecular weight marker (Invitrogen, Cergy Pontoise, France).

\section{Quantitative reverse transcriptase (Q)-PCR.}

Total RNA extraction was performed as described above. cDNA was prepared from $0.5 \mu \mathrm{g}$ purified RNA (High capacity cDNA reverse transcription kit, Applied Biosystems, Applied Biosystems, Courtaboeuf, France) and 25-fold diluted before use. Real time-PCR was performed with a spectrofluorometric thermal cycler (7900 HT Fast Real-Time PCR System, Applied Biosystems) following the manufacturer's recommendations, except for the final PCR volume that was decreased to $12 \mu 1$. IDO and PDL-1 primers and probes were purchased from Applied Biosystems (TaqMan assays-on-demand). Each data point was run in triplicate. To normalize the data, GAPDH was chosen as an endogenous control and tested in separate 
wells. The comparative $\mathrm{Ct}$ method was used to determine relative gene copy numbers. Firstly, the $\Delta \mathrm{Ct}$ was taken as equal to $\mathrm{Ct}$ of the antigen of interest minus $\mathrm{Ct}$ of GAPDH. The relative copy number of each antigen was then determined using the formula $2^{-\Delta \Delta \mathrm{Ct}}$, with $\Delta \Delta \mathrm{Ct}=\Delta \mathrm{Ct}$ (sample) $-\Delta \mathrm{Ct}$ (reference). The reference was a pool of RNA derived from three nonneoplastic brain samples. Samples with at least a 5-fold increase in mRNA expression compared to the reference were considered as positive.

\section{Immunohistochemistry.}

Immunohistochemistry was performed as described in (Saikali et al., 2007). Briefly, GBM sections from 20 GBM specimens unrelated to specimens used to generate GBM primary cell lines were deparaffinised and rehydrated in PBS, and then incubated for $30 \mathrm{~min}$ at $20^{\circ} \mathrm{C}$ with diluted primary antibodies against antigens (1/500, 1/50 and 1/100 dilutions for IDO, PDL-1 and vimentin, respectively). An additional incubation was performed with an anti-mouse or goat antibody (DakoCytomation) for $30 \mathrm{~min}$. Sections were revealed using the peroxidase substrate kit (Vector Laboratories, Vandoeuvre, France) and counterstained with hematoxylin. Microscopic analysis was performed using a Leitz-Diaplan microscope (Nuremburg, Germany). Results are expressed as the percentage of stained cells after counting 500 tumour cells in two different areas with the most intense expression, and represented as '-' for no expression, ' $-/+$ ' for $1-25 \%$; ' '’ for $26-50 \%$; ' ++ ' for $51-75 \%$ and ' +++ ' for $76-100 \%$ of analysed cells. GBM samples with less than $26 \%$ of positive cells are arbitrarily considered as negative.

\section{Flow cytometry.}

Cells were washed in PBS 2\% FCS and incubated with saturating concentrations of unlabelled or fluorescent-labelled primary antibodies for $30 \mathrm{~min}$ at $4^{\circ} \mathrm{C}$. An additional 
incubation with fluorescent-labelled secondary antibodies was performed when cells were stained with unlabelled primary antibodies. Cells were then washed with PBS 2\% FCS and analysed by flow cytometry using a FACScan flow cytometer (BD Biosciences). For intracellular staining, cells were fixed with methanol and permeabilised with saponin. Data were then analysed with the CellQuest software (BD Biosciences). Results are expressed as specific fluorescence intensity given by the ratio of the geometric mean of test divided by the geometric mean of the isotype control.

\section{TGF- $\beta 2$ secretion and IDO activity.}

Cells were washed in culture medium and incubated for 48 hours at a concentration of $1 \times 10^{6}$ cells per $\mathrm{ml}$ in the presence or not of $1000 \mathrm{U}$ per $\mathrm{ml}$ of IFN- $\gamma$ (Boehringer Ingelheim, Paris). Supernatants were then centrifuged at $400 \mathrm{~g}$ for $5 \mathrm{~min}$ and frozen at $-20^{\circ} \mathrm{C}$. IDO activity was evaluated by measuring tryptophan and kynurenin concentrations in culture supernatants by high performance liquid chromatography as described in (Widner et al., 1997). TGF- $\beta 2$ secretion was determined by ELISA following the manufacturer's instructions (R\&D Systems, Lille, France). Active form of TGF- $\beta 2$ was analyzed after acidification of supernatants with $\mathrm{HCl}$ according to the manufacturer's instructions.

\section{Generation of Melan-A/HLA-A2-specific CTLs.}

HLA-A2 positive peripheral blood mononuclear cells (PBMC) from healthy donors were prepared as described in (Avril et al., 2009). Peripheral blood lymphocytes (PBL) and monocytes were separated by elutriation (J6-MC centrifuge, Beckman Coulter, Villepinte, France). Cells were then frozen in a 4\% HSA (B Braun Medical SAS, Boulogne, France) 10\% DMSO (LFB Biomedicaments, Courtaboeuf) solution. Melan-A/HLA-A2-specific CTLs were 
generated in vitro after repeated stimulations with autologous Melan-A peptide-pulsed dendritic cells.

To generate dendritic cells, monocytes were defrosted, washed and cultured for 6 days in RPMI 10\% SVF supplemented with $1000 \mathrm{U}$ per ml of rhGM-CSF (Novartis, RueilMalmaison, France) and $200 \mathrm{U}$ per $\mathrm{ml}$ of rhIL-4 (AbCys, Paris) at $37^{\circ} \mathrm{C}$ in a humidified $5 \%$ $\mathrm{CO} 2$ incubator. Before use, dendritic cells were matured overnight with $1000 \mathrm{U}$ per $\mathrm{ml}$ of rhTNFa (CellGenix, Clermont l'Herault, France) and $50 \mu \mathrm{g}$ per $\mathrm{ml}$ of Poly IC (Sigma). Mature dendritic cells were then harvested, resuspended in RPMI at $2 \times 10^{6}$ cells per $\mathrm{ml}$ and incubated with $10 \mu \mathrm{g}$ per ml of Melan-A peptide (sequence: ELAGIGILTV, Genospheres Biotechnologies, Paris) for 1 hour at $37^{\circ} \mathrm{C}$.

CD8 $+\mathrm{T}$ cell population was enriched from autologous PBL after depletion of CD4+ cells using a magnetic microbeads (Dynal, Invitrogen). Enriched CD8+ T cells $\left(1 \times 10^{5}\right.$ cells per well) were cocultured with Melan-A-pulsed dendritic cells $\left(2 \times 10^{4}\right.$ cells per well) in $200 \mu 1$ of X-VIVO 15 medium (Lonza) supplemented with 5 ng per ml of rhIL-6 and rhIL-12 (TébuBio, Le Perray-en-Yvelines, France) in an 96U-well microplate. Lymphocytes were then restimulated once every week with freshly prepared autologous peptide-pulsed dendritic cells ( $1 \times 10^{4}$ cells per well), $20 \mathrm{U}$ per $\mathrm{ml}$ of rhIL-2 (Novartis) and $5 \mathrm{ng}$ per $\mathrm{ml}$ of rhIL-7 (Tébu-Bio). After 3 stimulations, cells expanded in each well were separately tested in a IFN- $\gamma$ release assay using Melan-A-pulsed HLA-A2+ T2 cells as targets. Cells from positive wells were pooled and expanded with additional stimulations using autologous peptide-pulsed dendritic cells. Melan-A/HLA-A2-specific CTLs generated were finally tested by flow cytometry for their expression of CD3 and CD8 $\mathrm{T}$ cell markers and their binding of Melan-A/HLA-A2 tetramer.

IFN- $\gamma$ release assay. 
Irradiated target cells were washed and plated in RPMI 10\% FCS at a concentration of $1 \times 10^{4}$ per well in a 96U-well microplate. Effector cells were washed and added onto the target cells at $5 \times 10^{4}$ cells per well. Blocking antibodies $(10 \mu \mathrm{g}$ per $\mathrm{ml})$ and 1 -methyltryptophane inhibitor $(400 \mathrm{mM})$ were added $15 \mathrm{~min}$ before the effectors. Cells were then incubated for 24 hours at $37^{\circ} \mathrm{C}$ at the final volume of $200 \mu 1$ per well. At the end of the assay, $150 \mu 1$ of supernatant were centrifuged and analysed for IFN- $\gamma$ by ELISA, following the manufacturer's instructions (Diaclone).

\section{Cytotoxicity assay.}

$5 \times 10^{6}$ target cells were labelled with $100 \mu \mathrm{Ci}$ of $\mathrm{Na}_{2}{ }^{51} \mathrm{CrO}_{4}$ (GE Healthcare, Orsay, France) for $90 \mathrm{~min}$ at $37^{\circ} \mathrm{C}$. Cells were washed twice in culture medium, resuspended in $1 \mathrm{ml}$ of culture medium and incubated for $60 \mathrm{~min}$ at $37^{\circ} \mathrm{C}$ to allow spontaneous release of 51chromium. After 3 washes in culture medium, target cells were plated in X-VIVO medium at a concentration of $2 \times 10^{4}$ cells per well in a 96U-well microplate. Effector cells were washed in X-VIVO medium and added onto the target cells at different effector:target ratios as indicated in the figure 5. Blocking antibodies $(10 \mu \mathrm{g}$ per $\mathrm{ml})$ and 1-methyltryptophane inhibitor $(400 \mathrm{mM})$ were added $15 \mathrm{~min}$ before the effectors and were present throughout the cytotoxicity assay. Cells were incubated for 4 or 24 hours at $37^{\circ} \mathrm{C}$ at the final volume of 200 $\mu 1$ per well. Spontaneous and maximum releases were obtained by incubating target cells with the medium alone and with triton $\mathrm{x}-100$, respectively. At the end of the assay, $50 \mu \mathrm{l}$ of supernatant were transferred into a scintillation microplate (Lumaplate 96, Perkin Elmer, Courtaboeuf), dried overnight at $54^{\circ} \mathrm{C}$ and the radioactivity was measured with a gamma counter (TopCount, Packard Instruments, Meriden, United-States). The percentage of specific lysis was determined as followed: ((cpm of test release - cpm of spontaneous release) / (cpm of maximum release - cpm of spontaneous release) $) * 100$. 
PHA-induced PBMC proliferation.

$1 \times 10^{5}$ PBMC were cocultured with irradiated $2 \times 10^{4}$ tumour cells in the presence of $1 \mu \mathrm{g}$ per $\mathrm{ml}$ of phytohemagglutinin (PHA) in a $96 \mathrm{U}$-well microplate for 3 days at $37^{\circ} \mathrm{C}$ in a humidified 5\% CO2 incubator. For IDO inhibition, 1-methyl tryptophan inhibitor (400 mM) was added. ${ }^{3} \mathrm{H}$ thymidine ( $1 \mathrm{mCi} /$ well; GE Healthcare) was added 18 hours before the end of the test. Cell incorporation of ${ }^{3} \mathrm{H}$ thymidine was revealed by adding a scintillation fluid (Perkin Elmer) and measured with a gamma counter (Topcount).

\section{Statistics.}

Values represent the mean \pm standard deviation of $\mathrm{n}$ different experiments. The Student $\mathrm{t}$-test is applied using a two-tailed distribution of two conditions of unequal or equal variances on groups of data obtained in the experiments. The significance level is $\mathrm{p}<0.05$. 


\section{RESULTS}

FasL, HLA-G, IDO, PDL-1 and TGF- $\beta 1-3$ mRNA expression in a series of GBM samples by expression microarray analysis.

We have recently reported a DNA target transcriptomic profiling on 20 GBM samples (de Tayrac et al., 2009). Using the complete microarray data set, FasL, HLA-G, IDO, PDL-1 and TGF- $\beta$ 1-3 transcripts expression was compared between GBM and non-tumour brain samples.

A significant increase (expression fold change greater than two) is observed in $15 \%, 60 \%$, $85 \%, 30 \%, 70 \%, 80 \%$, and $35 \%$ of GBM samples for FasL, HLA-G, IDO, PDL-1, TGF- $\beta 1$, $T G F-\beta 2$ and $T G F-\beta 3$, respectively (Figure 1).

FasL, HLA-G, IDO, PDL-1 and TGF- $\beta 1-3$ mRNA expression in GBM cell lines.

For in vitro assays, we have generated 10 GBM primary cell lines, and used U251 and U87MG cell lines. GBM cell lines as well as U251 and U87MG cell lines were characterised by their expression of vimentin, an intermediate filament highly expressed in GBM cells (supplementary data, Figure S1A), as well as by their lack of expression of a neural marker TujIII, and an oligodendrocytic marker O4 (data not shown). All GBM cell lines also expressed at least one of the tumour antigens IL13Ra2, EGFRvIII or gp100 that we previously reported on GBM (Saikali et al., 2007) (supplementary data, Figure S1B).

We then used RT-PCR to test mRNA expression of FasL, HLA-G, IDO, PDL-1 and TGF$\beta 1-3$ in GBM cell lines. Only 2 out of 10 GBM primary cell lines express FasL with a weak expression level compared to the positive control (Figure 2A). In addition, IFN- $\gamma$ treatment was found to reduce the FasL mRNA expression of the positive cell lines. Consequently, this molecule was not studied further. $H L A-G$ mRNA expression is not observed on GBM cell lines. Its expression is induced in only one out 10 GBM cell lines after IFN- $\gamma$ treatment 
(Figure 2B). In contrast, most GBM primary cell lines express $I D O, P D L-1$ and $T G F-\beta 1-3$ mRNA at the resting state (Figure $2 \mathrm{~A}$ ) or after IFN- $\gamma$ stimulation (Figure $2 \mathrm{~B}$ ).

HLA class I, HLA-G and PDL-1 protein expression in GBM cell lines.

Protein expression of HLA-G and PDL-1 was screened by flow cytometry on both untreated and IFN- $\gamma$-treated GBM cell lines. As shown in Figure 3, the expression of MHC class I molecules is increased after IFN- $\gamma$ treatment, demonstrating the efficiency of this treatment. In addition, expression of PDL-1 and HLA-G is observed in the positive controls IFN- $\gamma$ treated monocytes and the JEG-3 trophoblastic cell line, respectively. However, none of the GBM cell lines express HLA-G even after IFN- $\gamma$ stimulation. On the other hand, PDL-1 is expressed on most GBM cell lines (9 out of 10), while IFN- $\gamma$ stimulation induces or increases the expression of this protein in all cell lines (Figure 3).

IDO protein expression and activity in GBM cell lines.

The IDO protein expression was analysed by immunohistochemistry. Only a low proportion of untreated GBM cell lines express IDO (around 25\% on average), except GBM\#4 (around 55\%) (Figure 4A, Table 2), while the IDO expression increases in all GBM cell lines treated by IFN- $\gamma$. Interestingly, the immunostaining intensity is lower on untreated cells compared with IFN- $\gamma$-treated cells (Figure 4A).

The IDO activity in the supernatants of GBM cell lines was thereafter obtained by determining the level of tryptophan and kynurenin, this latter molecule being a degradation product of tryptophan. IDO activity is observed in half of the untreated GBM primary cell lines tested, being particularly high in GBM\#4. IFN- $\gamma$ stimulation induces or increases IDO activity in all the GBM cell lines (Figure 4B). 
TGF- $\beta 2$ secretion by GBM cell lines.

TGF- $\beta 2$ secretion is observed at various levels in the supernatants of 9 out of 10 untreated GBM cell lines (Figure 4C). Detection is observed only after acidification of the supernatants, suggesting that the latent form of TGF- $\beta 2$ is mainly produced by GBM cell lines. Unexpectedly, IFN- $\gamma$ treatment significantly reduces the secretion of TGF- $\beta 2$.

Melan-A/HLA-A2-specific T cell recognition of Melan-A-loaded GBM cell lines.

To test the involvement of IDO, PDL1 and TGF- $\beta 1-3$ molecules in the sensibility of GBM cell lines to the effectors functions of $\mathrm{T}$ cells, we expanded antigen-specific $\mathrm{T}$ cell lines capable of recognizing GBM cell lines. Despite several attempts, we were unable to expand the IL13R $\alpha 2 / H L A-A 2-s p e c i f i c$ T cell lines as previously reported by Okano et al. (Okano et al., 2002). We therefore generated Melan-A/HLA-A2-specific T cell lines and tested them for Melan-A/HLA-A2 tetramer staining. As shown in Figure 5A, 80\% of cells from $\mathrm{T}$ cell line cultures are CD8+ T cells which bind to the Melan-A/HLA-A2 tetramer. In addition, T cells secrete IFN- $\gamma$ when they are cultivated in the presence of Melan-A-loaded T2 cells, which are used here as positive controls (Figure 5B). To test the recognition of GBM cell lines by these Melan-A/HLA-A2-specific T cell lines, GBM cells are unloaded or loaded with Melan-A peptides and cultivated with the $\mathrm{T}$ cell lines. Melan-A/HLA-A2-specific $\mathrm{T}$ cells are able to secrete IFN- $\gamma$ when in the presence of Melan-A-loaded GBM primary cells, but not in the presence of unloaded GBM cells. Interestingly, a drastic reduction in T cell IFN- $\gamma$ secretion is observed when Melan-A/HLA-A2-specific T cells are cultivated in the presence of Melan-Aloaded GBM cells pre-treated by IFN- $\gamma$ (Figure 5B). T cells lines were then used as cytotoxic effectors against unloaded or Melan-A-loaded T2 cells and GBM primary cells. As shown in Figure 5C, Melan-A/HLA-A2-specific T cells kill Melan-A-loaded T2 and GBM cells, but 
not unloaded cells. Again, T cell cytotoxicity is reduced against Melan-A-loaded GBM cells when they are pre-treated by IFN- $\gamma$.

Role of IDO, PDL-1 and TGF- $\beta 1-3$ on IFN- $\gamma$ release and cell cytotoxicity of specific T cells. Melan-A/HLA-A2-specific $\mathrm{T}$ cells were used as effectors in IFN- $\gamma$ secretion and cell cytotoxicity assays against GBM cells in the presence of blocking antibodies against PDL-1 or TGF- $\beta 1-3$ and in the presence of 1-methyl-tryptophan, an inhibitor of the IDO enzyme. These reagents have neither effect on IFN- $\gamma$ secretion nor cell cytotoxicity functions of Melan-A/HLA-A2-specific T cells against T2 cells (Figure 5D and 5E). By contrast, the presence of anti-PDL-1 antibodies increased the IFN- $\gamma$ secretion of specific $\mathrm{T}$ cells in response to untreated or IFN- $\gamma$-pre-treated Melan-A-loaded GBM cells (Figure 5D) demonstrating the involvement of PDL-1 in the inhibition of T cell IFN- $\gamma$ secretion. On the other hand, the inhibitors of TGF- $\beta 1-3$ and IDO had no effect on IFN- $\gamma$ secretion of specific T cells. None of the inhibitors tested have any effect as regards the cell cytotoxicity function, irrespective of whether the cytotoxicity assay lasted for 4 hours or 24 hours (Figure 5E and data not shown). Supernatants of untreated and IFN- $\gamma$-treated GBM cell lines were also tested for their ability to inhibit IFN- $\gamma$ secretion of Melan-A-specific T cells in response to Melan-A loaded T2 cells. Only a modest inhibition (around 25\%) was observed with untreated GBM supernatants but not with IFN- $\gamma$-treated GBM supernatants (supplementary data, Figure S2). Furthermore, this inhibition was abolished by anti-TGF- $ß 1-3$ antibodies (see supplementary data, Figure S2).

Role of IDO on PHA-induced PBMC proliferation.

IDO has been previously reported as being involved in the inhibition of lymphocyte proliferation. We tested the lectin-induced PBMC proliferation with GBM primary cell lines 
in the presence of the IDO inhibitor, 1-methyl-tryptophan. As expected, lectin PHA induces the proliferation of PBMC, and the presence of allogenic T2 cells enhances this effect (Figure 6). In contrast, the PHA-induced proliferation of PBMC is reduced in the presence of GBM cells. Remarkably, this decrease is amplified when the GBM cells are pre-treated with IFN- $\gamma$ (Figure 6). The use of 1-methyl-tryptophan partially restores the inhibition of PBMC proliferation, suggesting a direct anti-proliferating role of IDO on PBMC.

$I D O$ and PDL-1 mRNA and protein expressions in a series of 20 GBM samples.

To confirm the presence of IDO and PDL-1 molecules in vivo within the tumour, 20 additional GBM samples were tested for mRNA expression of IDO and PDL-1 by Q-PCR and were immunohistochemically stained with anti-PDL-1 and IDO antibodies. mRNA expression was confirmed in 16 and 10 out of 20 GBM specimens for IDO (80\%) and PDL-1 (50\%) respectively (Figure 7A). Immunohistochemical expressions of PDL-1 and IDO were first confirmed in positive controls i.e. urothelial carcinoma and placenta samples, respectively. All of 20 GBM samples express IDO but only 45\% express PDL-1 (Figure 7B, Table 3). A correlation between mRNA and protein expression was observed for PDL-1 but not for IDO (Figure 7C). 


\section{DISCUSSION}

In this study, we analyse the expression of five immunoregulatory molecules FasL, HLA-G, PDL-1, IDO and TGF- $\beta 1-3$ in human GBM. Using GBM primary cell lines, we confirm the mRNA and protein expression of PDL-1, IDO and TGF- $\beta 2$ molecules in most of the GBM cell lines. Furthermore, functional studies highlight the role of PDL-1, TGF- $\beta 1-3$ and IDO in the inhibition of IFN- $\gamma$ production by tumour-specific T cells and lectin-induced lymphocyte proliferation, respectively. None of these molecules are involved in the resistance of GBM to tumour-specific T cell cytotoxicity.

IFN- $\gamma$ is a pleotropic cytokine that is generally undetectable within the central nervous system. Nevertheless, in response to brain infections or brain disorders such as multiple sclerosis, IFN- $\gamma$ is produced locally in large amounts by reactive $\mathrm{T}$ cells, but also activated astrocytes and microglial cells (Popko et al., 1997), (Suzuki et al., 2005). Due to the inflammatory context induced by cancer, production of IFN- $\gamma$ could be observed during tumoral processes in patients suffering from GBM. In addition, it has been shown that brain tumours and peritumoral regions express IFN- $\gamma$ mRNA (Nitta et al., 1994). More recently, elevated IFN- $\gamma$ serum concentrations have been reported in brain tumour patients compared to healthy donors (Mkhoyan et al., 2008). Considering these different points, we decided to investigate the immunoregulatory properties of resting or IFN- $\gamma$-treated GBM cells.

FasL and HLA-G expression has been previously reported in both GBM primary and immortalised cell lines as well as GBM specimens. FasL mRNA expression has been described by RT-PCR method in 6 out of 8 GBM immortalised cell lines and in 2 out of 6 primary tumours (Gratas et al., 1997). The southern-blotting approach markedly increased the 
detection of positive samples (Gratas et al., 1997). The FasL protein was also present in most of the GBM specimens analysed by western-blotting (4 out of 5) (Saas et al., 1997), and immunohistochemistry (overall 58 out of 59) (Gratas et al., 1997), (Saas et al., 1997), (Strege et al., 2004). However, the expression level observed by flow cytometry within GBM primary cell lines was always very low (Saas et al., 1997), (Chahlavi et al., 2005). Using genomic microarray and conventional RT-PCR techniques, we only observe FasL mRNA expression in 3 out of 20 GBM specimens and in 2 out of 10 GBM primary cell lines. In addition, IFN- $\gamma$ treatment diminishes significantly the Fas $L$ mRNA expression of the positive cell lines. For these reasons, the FasL molecule was not analysed further in our study.

$H L A-G$ mRNA expression has been previously described within respectively 6 and 10 out 12 untreated and IFN- $\gamma$-treated glioma immortalised cell lines (Wiendl et al., 2002). In the present study, none of the untreated GBM primary or immortalised cell lines express $H L A-G$ mRNA, while its expression is observed in only one of the IFN- $\gamma$-treated GBM primary cell lines tested. This discrepancy might be due to the sensitivity of the methods used i.e. conventional RT-PCR in our study as against northern-blotting in (Wiendl et al., 2002). Differences in cell lines origin might also be incriminated: GBM primary cell lines versus glioma immortalised cell lines. In contrast to the lack of $H L A-G$ mRNA expression in our GBM primary cell lines, 12 out of 20 GBM specimens tested expressed $H L A-G$ mRNA according to our transcriptomic data. This could be due to the cell heterogeneity of the entire tumour used, which not only includes tumour cells, but also comprises a microenvironment compartment i.e. other locally recruited or infiltrated cells. It is now well known that cells from different origins can express HLA-G molecules (Amiot et al., 1998). Thus, we cannot rule out the possibility that these non-tumour cells contribute alone to the HLA-G expression detected by our transcriptomic microarray analysis. Using flow cytometry, we fail to detect any HLA-G protein expression on the cell surface of the GBM primary cell lines, as well as 
with U251 and U87 cells, even following treatment with IFN- $\gamma$. This is in agreement with the lack of HLA-G expression reported by a wide variety of solid tumours and especially in brain tumour specimens (Bainbridge et al., 2001), (Davies et al., 2001). Therefore, HLA-G was not taken into consideration in further functional assays.

Increased production of TGF- $\beta 1-3$ occurs in various tumour types and correlates with tumour grade. (Bodmer et al., 1989), (Leitlein et al., 2001), (Pasche, 2001). TGF- $\beta 2$ has been considered to play a crucial role in both malignant progression of glial tumours and immune dysfunction in human GBM patients (Weller and Fontana, 1995). Transcript and protein expression of TGF- $\beta 1-3$ has long been known in malignant gliomas (Weller and Fontana, 1995). In glioma cell lines, TGF- $\beta 1-3$ were mainly documented in their small and large latent forms rather than their mature bioactive forms (Constam et al., 1992), (Olofsson et al., 1992). In the present study, we show that all untreated and IFN- $\gamma$-treated GBM cell lines express TGF- $\beta 2$ transcripts. However, various levels of TGF- $\beta 2$ secretion are observed between untreated GBM cell lines. This suggests that expression of TGF- $\beta 2$ protein is finely regulated at the post- transcriptional level. Noticeably, the IFN- $\gamma$ treatment decreases TGF- $\beta 2$ secretion in all the GBM cell lines analysed. In addition, TGF- $\beta 2$ from culture supernatants of GBM primary and immortalised cell lines can only be detected after acidification. This suggests that TGF- $\beta 2$ is mostly secreted in its latent form. TGF- $\beta 1-3$ have an important role in the regulation of anti-tumour immune responses, including the maturation of dendritic cells (Gorelik and Flavell, 2002) or the activation of T and NK cells (Thomas and Massagué, 2005), (Eisele et al., 2006). TGF- $\beta 1$ acts directly on CD8 T cell cytotoxicity by inhibiting the expression of FasL, perforin, granzymes $A / B$ and $I F N-\gamma$ genes (Thomas and Massagué, 2005). In this study, using blocking antibodies against TGF- $\beta 1-3$, we fail to show any effect of TGF$\beta 1-3$ in regulating $\mathrm{T}$ cell cytotoxicity against GBM primary cell lines. One plausible reason is 
that the latent or complex form of TGF- $\beta 2$, the predominant isoform of TGF- $\beta$ secreted by GBM cells (Leitlein et al., 2001), might not be cleaved during the 4-hour cytotoxicity assay, thus preventing its action on $\mathrm{T}$ cells. Indeed, the TGF- $\beta 1$ effects on $\mathrm{T}$ cell cytotoxicity previously described in (Thomas and Massagué, 2005) can be obtained by pre-treating T cells typically for 24 hours before the cytotoxicity assay. Alternatively, in contrast to TGF- $\beta 1$, TGF- $\beta 2$ might have no direct effect on T cell cytotoxicity. Using Melan-A-loaded GBM cells as target cells, no inhibitory effect of TGF $\beta 1-3$ is observed on IFN- $\gamma$ secretion of Melan-Aspecific T cells. In contrast, supernatants of untreated GBM primary cell lines partially inhibit the IFN- $\gamma$ secretion of specific T cells in response to Melan-A-loaded T2 target cells (see supplementary data, Figure S2); and this inhibition is completely reversed by anti-TGF- $\beta 1-3$ blocking antibodies. This suggests that at least a fraction of TGF- $\beta 1-3$ is functional in this model and can inhibit $\mathrm{T}$ cell IFN- $\gamma$ production. This discrepancy in the effect of TGF- $\beta 1-3$ on T cell IFN- $\gamma$ secretion might be due to the difference of concentration of TGF- $\beta 1-3$ present in the two different models tested: the GBM cell concentration was 20 fold higher in experiments with supernatants. The mechanisms that regulate the activation of TGF- $\beta 1-3$ are complex and not well fully understood. Small and large latent forms of TGF- $\beta 1-3$ are converted to active forms of TGF- $\beta 1-3$ by proteases such as metalloproteases of the extracellular matrix. Latent forms could also directly interact with cell surface receptors that change their conformation and release the activated TGF- $\beta 1-3$ in an autocrine or a paracrine manner (Taylor, 2009). One could speculate that this phenomena is occurring in our IFN- $\gamma$ secretion model.

In this work, we confirm the expression of IDO and PDL-1 in both GBM primary cell lines and tumour specimens at the mRNA and protein levels. PDL-1 expression was previously described in 12 untreated and IFN- $\gamma$-treated glioma immortalised cell lines (Wintterle et al., 
2003); 6 out of 7 GBM primary cell lines (Wilmotte et al., 2005) and in all of the 28 GBM specimens analysed (Wintterle et al., 2003), (Wilmotte et al., 2005). In this work, all untreated (except one) and IFN- $\gamma$-treated GBM cell lines express PDL-1 transcripts. However, variable protein expression levels are shown in the different untreated GBM cell lines. In addition, a correlation is observed in GBM specimens between mRNA level evaluated by Q-PCR and protein expression studied by immunohistochemistry. More than substantiating PDL-1 expression in about half of the GBM specimens, with various proportions of positive tumour cells, this works highlights the functional role of PDL-1. This is the first study demonstrating that PDL-1 reduces IFN- $\gamma$ production by $\mathrm{T}$ cells, in a tumour antigen-specific $\mathrm{T}$ cell model. This is in accordance with previous results obtained using allogenic CD4 and CD8 T cells (Wintterle et al., 2003) and superantigen-reactive T cells (Wilmotte et al., 2005).

Expression of the enzyme IDO has previously been shown in glioma immortalised cell lines (Grant and Kapoor, 2003), (Miyazaki et al., 2009) and GBM specimens (Uyttenhove et al., 2003). We confirm mRNA and protein expression in both GBM primary cell lines and tumour specimens. As shown with other cell types in previous studies (Munn and Mellor, 2007), (Corm et al. 2009); differences between IDO mRNA, protein expression and IDO activity are observed in most of GBM cell lines. Using GBM specimens, a lack of correlation is also observed between mRNA expression detected by Q-PCR and protein expression detected by immunohistochemistry. This could be due to the heterogeneity of the tumour samples, but could also reflect the complex regulation of IDO gene, protein and enzymatic activity that is still not fully elucidated. In agreement with previous results obtained with immortalised GBM cell lines (Grant and Kapoor, 2003), (Miyazaki et al., 2009), we show that all the GBM cell lines treated with IFN- $\gamma$ exhibit an IDO activity. Interestingly, IDO activity is also observed without any treatment in half of the cell lines. Moreover, the present study originally highlights the IDO functional role in GBM. Indeed, the IDO activity of GBM cell lines 
directly inhibits the lectin-dependent proliferation of human lymphocytes. Similar results have recently been described with ovarian cancer cells using an anti-CD3/28-induced $\mathrm{T}$ cell proliferation assay (Qian et al., 2009).

Concerning the functional assays with tumour-specific $\mathrm{T}$ cells, we first decided to use IL13R $\alpha 2$ as a molecular target for GBM cells because this antigen is frequently expressed in GBM samples (Saikali et al., 2007). Indeed, we observed IL13R $\alpha 2$ expression in all except one GBM primary cell line. Unfortunately, despite several attempts, we were unable to expand unmodified or modified IL13R $\alpha 2$-specific T cells as previously described in (Okano et al., 2002), (Eguchi et al., 2006). Even though we could confirm the presence of a small fraction (around 20\%) of IL13R $\alpha 2$-specific $\mathrm{T}$ cells at the third stimulation by tetramer staining, all of $\mathrm{T}$ cells died subsequently to additional stimulations (data not shown). Recently, Zhang et al. have reported the expression of MART-1/Melan-A antigen in glioma immortalised cell lines such as U251 and U87MG and pointed out that the fact that Melan-Aspecific $\mathrm{T}$ cell clones could recognize and kill of these cells (Zhang et al., 2007). In our laboratory, Melan-A-specific T cell lines were generated and tested for IFN- $\gamma$ production and cytotoxic activity in response to HLA-A2-positive GBM primary and U251 cell lines. Surprisingly, we are only able to show IFN- $\gamma$ production or cytotoxic responses occurred only when target cells are loaded with Melan-A peptides, suggesting that GBM cells do not efficiently present Melan-A peptides on their surface. This suggests that GBM does not express MART-1 antigen. Indeed, Zhang et al. have show that only 4 out of 25 GBM specimens express Melan-A mRNA by quantitative PCR and microarray analyses (Zhang et al., 2007). Furthermore, in our laboratory, we fail to observe the Melan-A expression in a series of 34 GBM samples by quantitative RT-PCR (data not shown). 
Using Melan-A-loaded GBM cell lines as target cells, we show that Melan-A-specific T cell lines recognize these target cells and, in response, produce IFN- $\gamma$ and thus kill the cells. However, the pre-treatment of GBM cells with IFN- $\gamma$ reduces markedly the IFN- $\gamma$ secretion and decreases the cytotoxicity activity of specific $\mathrm{T}$ cells, whereas it increases the expression of HLA class I molecules, which are the molecular targets for $\mathrm{T}$ cell recognition. We can speculate that novel immunoregulatory molecules might be induced by IFN- $\gamma$ and thus inhibit T cell functions. We demonstrate that PDL-1 is, at least in part, involved in the inhibition of T cell IFN- $\gamma$ production. However, none of the molecules PDL-1, IDO and TGF- $\beta 1-3$ have any direct role in inhibiting the $\mathrm{T}$ cell cytotoxic function. Identification of the molecules involved in this process is currently under investigation in our laboratory. In vivo, we should expect tumour resistance to $\mathrm{T}$ cell mediated responses to be finely regulated in GBM patients. On the one hand, tumour infiltrating $\mathrm{T}$ cells would locally produce IFN- $\gamma$ that could directly act on tumour cells by over-expressing molecules such as HLA class I molecules, which would therefore increase the tumour recognition by other T cells. On the other hand, IFN- $\gamma$-exposed tumour cells would up-regulate molecules such as PDL-1 and IDO that inhibit T cell functions. As a result, tumour cells would adapt and reinforce their resistance to $\mathrm{T}$ cell responses.

Immunotherapy is a promising new approach to cure GBM patients (Yamanaka, 2008). It is noteworthy that patients treated with dendritic cell vaccinations have demonstrated intratumour infiltration of cytotoxic T cells (Yamanaka et al., 2003), (Kikuchi et al., 2004), (Yu et al., 2004). However, as we show here, we should not underestimate the immunosuppressive properties of the tumour, which involve molecules such as PDL-1, IDO and TGF- $\beta 2$. This suggests that the immunotherapy approach has to be multimodal and should combine activators of immune cell effectors and inhibitors that counteract the immunosuppressive 
activities of the tumour. Novel inhibitors of IDO, PDL-1 and TGF- $\beta 2$ have been recently developed and are currently investigated in phase I/II clinical trials. The novel IDO enzyme inhibitor 1MT has recently been used in a phase I study in refractory solid malignancies (Soliman et al., 2009). Both the safety and efficiency of this treatment have been demonstrated, and future trials will combine 1-MT with other immunotherapies and chemotherapies in solid tumours. In addition, two antibodies CT-011 and MDX-1106 against PD-1, that block its interaction with the ligands PDL-1 and -2, have been recently developed and are currently used in phase II clinical trials in advanced hematological malignancies (Berger et al., 2008), as well as refractory or relapsed solid tumours of lung, kidney, colon skin and prostate (Brahmer et al., 2009). In summarize, it is hoped that the development of such molecules will provide essential adjuvants that will improve the efficiency of GBM patients treatment by immunotherapy involving $\mathrm{T}$ cell responses. 


\section{REFERENCES}

Amiot L., Onno M., Drénou B., Monvoisin C., Fauchet R. 1998. HLA-G class I gene expression in normal and malignant hematopoietic cells. Hum. Immunol. 59, 524-528.

Avril T., de Tayrac M., Leberre C., Quillien V. 2009. Not all polyriboinosinicpolyribocytidylic acids (Poly I:C) are equivalent for inducing maturation of dendritic cells: implication for alpha-type-1 polarized DCs. J. Immunother. 32, 353-362.

Bainbridge D., Ellis S., Le Bouteiller P., Sargent I. 2001. HLA-G remains a mystery. Trends Immunol. 22, 548-552.

Berger R., Rotem-Yehudar R., Slama G., Landes S., Kneller A., Leiba M., Koren-Michowitz M., Shimoni A., Nagler A. 2008. Phase I safety and pharmacokinetic study of CT-011, a humanized antibody interacting with PD-1, in patients with advanced hematologic malignancies. Clin. Cancer Res. 14, 3044-3051.

Bodmer S., Strommer K., Frei K., Siepl C., de Tribolet N., Heid I., Fontana A. 1989. Immunosuppression and transforming growth factor-beta in glioblastoma. Preferential production of transforming growth factor-beta 2. J. Immunol. 143, 3222-3229.

Brahmer R., Topalian S.L., Powderly J., Wollner I., Picus J., Drake C.G., Stankevich E., Korman A., Pardoll D., Lowy I. 2009. Phase II experience with MDX-1106 (Ono-4538), an anti-PD-1 monoclonal antibody, in patients with selected refractory or relapsed malignancies. J. Clin. Oncol (Meeting Abstracts) 27, 3018. 
Carosella E.D., Favier B., Rouas-Freiss N., Moreau P., Lemaoult J. 2008. Beyond the increasing complexity of the immunomodulatory HLA-G molecule. Blood. 111, 4862-4870.

Chahlavi A., Rayman P., Richmond A.L., Biswas K., Zhang R., Vogelbaum M., Tannenbaum C., Barnett G., Finke J.H. 2005. Glioblastomas induce T-lymphocyte death by two distinct pathways involving gangliosides and CD70. Cancer Res. 65, 5428-5438.

Chang C.C., Ferrone S. 2003. HLA-G in melanoma: can the current controversies be solved? Semin. Cancer Biol. 13, 361-369.

Constam D.B., Philipp J., Malipiero U.V., ten Dijke P., Schachner M., Fontana A. 1992. Differential expression of transforming growth factor-beta 1, -beta 2, and -beta 3 by glioblastoma cells, astrocytes, and microglia. J. Immunol. 148, 1404-1410.

Corm S., Berthon C., Imbenotte M., Biggio V., Lhermitte M., Dupont C., Briche I., Quesnel B. 2009. Indoleamine 2,3-dioxygenase activity of acute myeloid leukemia cells can be measured from patients' sera by HPLC and is inducible by IFN-gamma. Leuk Res. 33. 490494.

Davies B., Hiby S., Gardner L., Loke Y.W., King A. 2001. HLA-G expression by tumors. Am. J. Reprod. Immunol. 45, 103-107. 
Dong H., Strome S.E., Salomao D.R., Tamura H., Hirano F., Flies D.B., Roche P.C., Lu J., Zhu G., Tamada K., Lennon V.A., Celis E., Chen L. 2002. Tumor-associated B7-H1 promotes T-cell apoptosis: a potential mechanism of immune evasion. Nat. Med. 8, 793-800.

Eguchi J., Hatano M., Nishimura F., Zhu X., Dusak J.E., Sato H., Pollack I.F., Storkus W.J., Okada H. 2006. Identification of interleukin-13 receptor alpha2 peptide analogues capable of inducing improved antiglioma CTL responses. Cancer Res. 66, 5883-5891.

Eisele G., Wischhusen J., Mittelbronn M., Meyermann R., Waldhauer I., Steinle A., Weller M., Friese M.A. 2006. TGF-beta and metalloproteinases differentially suppress NKG2D ligand surface expression on malignant glioma cells. Brain. 129, 2416-2425.

Freeman G.J., Long A.J., Iwai Y., Bourque K., Chernova T., Nishimura H., Fitz L.J., Malenkovich N., Okazaki T., Byrne M.C., Horton H.F., Fouser L., Carter L., Ling V., Bowman M.R., Carreno B.M., Collins M., Wood C.R., Honjo T. 2000. Engagement of the PD-1 immunoinhibitory receptor by a novel B7 family member leads to negative regulation of lymphocyte activation. J. Exp. Med. 192, 1027-1034.

Gorelik L., Flavell R.A. 2002. Transforming growth factor-beta in T-cell biology. Nat. Rev. Immunol. 2, 46-53.

Grant R., Kapoor V. 2003. Inhibition of indoleamine 2,3-dioxygenase activity in IFN-gamma stimulated astroglioma cells decreases intracellular NAD levels. Biochem. Pharmacol. 66, 1033-1036. 
Gratas C., Tohma Y., Van Meir E.G., Klein M., Tenan M., Ishii N., Tachibana O., Kleihues P., Ohgaki H. 1997. Fas ligand expression in glioblastoma cell lines and primary astrocytic brain tumors. Brain Pathol. 7, 863-869.

Greenwald R.J., Freeman G.J., Sharpe A.H. 2005. The B7 family revisited. Annu. Rev Immunol. 23, 515-548.

Katz J.B., Muller A.J., Prendergast G.C. 2008. Indoleamine 2,3-dioxygenase in T-cell tolerance and tumoral immune escape. Immunol. Rev. 222, 206-221.

Kikuchi T., Akasaki Y., Abe T., Fukuda T., Saotome H., Ryan J.L., Kufe D.W., Ohno T. 2004. Vaccination of glioma patients with fusions of dendritic and glioma cells and recombinant human interleukin 12. J. Immunother. 27, 452-459.

Kovats S., Main E.K., Librach C., Stubblebine M., Fisher S.J., DeMars R. 1990. A class I antigen, HLA-G, expressed in human trophoblasts. Science. 248, 220-223.

Leitlein J., Aulwurm S., Waltereit R., Naumann U., Wagenknecht B., Garten W., Weller M., Platten M. 2001. Processing of immunosuppressive pro-TGF-beta 1,2 by human glioblastoma cells involves cytoplasmic and secreted furin-like proteases. J. Immunol. 166, 7238-7243.

Liau L.M., Prins R.M., Kiertscher S.M., Odesa S.K., Kremen T.J., Giovannone A.J., Lin J.W., Chute D.J., Mischel P.S., Cloughesy T.F., Roth M.D. 2005. Dendritic cell vaccination in glioblastoma patients induces systemic and intracranial T-cell responses modulated by the local central nervous system tumor microenvironment. Clin. Cancer Res. 11, 5515-5525. 
Miyazaki T., Moritake K., Yamada K., Hara N., Osago H., Shibata T., Akiyama Y., Tsuchiya M. 2009. Indoleamine 2,3-dioxygenase as a new target for malignant glioma therapy. J. Neurosurg. J Neurosurg. 111, 230-237.

Mkhoyan G.G., Ter-Pogossian Z.R., Gasparyan M.G., Dzhagatspanyan N.G., Hovhannesyan G.G. 2008. Cytokine regulation of immune response in patients with a brain tumor or injury. Neurochemical Journal. 25, 318-319.

Munn D.H., Mellor A.L. 2007. Indoleamine 2,3-dioxygenase and tumor-induced tolerance. J. Clin. Invest. 117, 1147-1154.

Munn D.H., Shafizadeh E., Attwood J.T., Bondarev I., Pashine A., Mellor A.L. 1999. Inhibition of $\mathrm{T}$ cell proliferation by macrophage tryptophan catabolism. J. Exp. Med. 189, $1363-1372$.

Munn D.H., Zhou M., Attwood J.T., Bondarev I., Conway S.J., Marshall B., Brown C., Mellor A.L. 1998. Prevention of allogeneic fetal rejection by tryptophan catabolism. Science. 281, 1191-1193.

Nagata S., Golstein P. 1995. The Fas death factor. Science. 267, 1449-1456.

Nitta T., Ebato M., Sato K., Okumura K. 1994. Expression of tumour necrosis factor-alpha, beta and interferon-gamma genes within human neuroglial tumour cells and brain specimens. Cytokine. 6, 171-180. 
Okano F., Storkus W.J., Chambers W.H., Pollack I.F., Okada H. 2002. Identification of a novel HLA-A*0201-restricted, cytotoxic T lymphocyte epitope in a human glioma-associated antigen, interleukin 13 receptor alpha2 chain. Clin. Cancer Res. 8, 2851-2855.

Olofsson A., Miyazono K., Kanzaki T., Colosetti P., Engström U., Heldin C.H. 1992. Transforming growth factor-beta 1, -beta 2, and -beta 3 secreted by a human glioblastoma cell line. Identification of small and different forms of large latent complexes. J. Biol. Chem. 267, 19482-19488.

Pasche B. 2001. Role of transforming growth factor beta in cancer. J. Cell Physiol. 186, 153168.

Popko B., Corbin J.G., Baerwald K.D., Dupree J., Garcia A.M. 1997. The effects of interferon-gamma on the central nervous system. Mol Neurobiol. 14, 19-35.

Qian F., Villella J., Wallace P.K., Mhawech-Fauceglia P., Tario J.D. Jr, Andrews C., Matsuzaki J., Valmori D., Ayyoub M., Frederick P.J., Beck A., Liao J., Cheney R., Moysich K., Lele S., Shrikant P., Old L.J., Odunsi K. 2009. Efficacy of levo-1-methyl tryptophan and dextro-1-methyl tryptophan in reversing indoleamine-2,3-dioxygenase-mediated arrest of Tcell proliferation in human epithelial ovarian cancer. Cancer Res. 69, 5498-5504.

Saas P., Walker P.R., Hahne M., Quiquerez A.L., Schnuriger V., Perrin G., French L., Van Meir E.G., de Tribolet N., Tschopp J., Dietrich P.Y. 1997 Fas ligand expression by 
astrocytoma in vivo: maintaining immune privilege in the brain? J. Clin. Invest. 99, 11731178.

Saikali S., Avril T., Collet B., Hamlat A., Bansard J.Y., Drenou B., Guegan Y., Quillien V. 2007. Expression of nine tumour antigens in a series of human glioblastoma multiforme: interest of EGFRvIII, IL-13Ralpha2, gp100 and TRP-2 for immunotherapy. J. Neurooncol. $81,139-148$.

Soliman H.H., Antonia S., Sullivan D., Vanahanian N., Link C., Lee H. 2009. Overcoming tumor antigen anergy in human malignancies using the novel indeolamine 2,3-dioxygenase (IDO) enzyme inhibitor, 1-methyl-D-tryptophan (1MT). J. Clin. Oncol (Meeting Abstracts) 27,3004 .

Strege R.J., Godt C., Stark A.M., Hugo H.H., Mehdorn H.M. 2004. Protein expression of Fas, Fas ligand, Bcl-2 and TGFbeta2 and correlation with survival in initial and recurrent human gliomas. J. Neurooncol. 67, 29-39.

Stupp R., Hegi M.E., Mason W.P., van den Bent M.J., Taphoorn M.J., Janzer R.C., Ludwin S.K., Allgeier A., Fisher B., Belanger K., Hau P., Brandes A.A., Gijtenbeek J., Marosi C., Vecht C.J., Mokhtari K., Wesseling P., Villa S., Eisenhauer E., Gorlia T., Weller M., Lacombe D., Cairncross J.G., Mirimanoff R.O.; European Organisation for Research and Treatment of Cancer Brain Tumour and Radiation Oncology Groups; National Cancer Institute of Canada Clinical Trials Group. 2009. Effects of radiotherapy with concomitant and adjuvant temozolomide versus radiotherapy alone on survival in glioblastoma in a randomised phase III study: 5-year analysis of the EORTC-NCIC trial. Lancet Oncol. 10, 459-466. 
Stupp R., Mason W.P., van den Bent M.J., Weller M., Fisher B., Taphoorn M.J., Belanger K., Brandes A.A., Marosi C., Bogdahn U., Curschmann J., Janzer R.C., Ludwin S.K., Gorlia T., Allgeier A., Lacombe D., Cairncross J.G., Eisenhauer E., Mirimanoff R.O. 2005. Radiotherapy plus concomitant and adjuvant temozolomide for glioblastoma. N. Engl. J. Med. $352,987-996$.

Suzuki Y., Claflin J., Wang X., Lengi A., Kikuchi T. 2004. Microglia and macrophages as innate producers of interferon-gamma in the brain following infection with Toxoplasma gondii. Int J Parasitol. 35, 83-90.

Taylor AW. 2009. Review of the activation of TGF-beta in immunity. J Leukoc Biol. 85, 2933.

de Tayrac M., Etcheverry A., Aubry M., Saïkali S., Hamlat A., Quillien V., Le Treut A., Galibert M.D., Mosser J. 2009. Integrative genome-wide analysis reveals a robust genomic glioblastoma signature associated with copy number driving changes in gene expression. Genes Chromosomes Cancer. 48, 55-68.

Thomas D.A., Massagué J. 2005. TGF-beta directly targets cytotoxic T cell functions during tumor evasion of immune surveillance. Cancer Cell. 8, 369-380.

Uyttenhove C., Pilotte L., Théate I., Stroobant V., Colau D., Parmentier N., Boon T., Van den Eynde B.J. 2003. Evidence for a tumoral immune resistance mechanism based on tryptophan degradation by indoleamine 2,3-dioxygenase. Nat. Med. 9, 1269-1274. 
Walker P.R., Calzascia T., Dietrich P.Y. 2002. All in the head: obstacles for immune rejection of brain tumours. Immunology. 107, 28-38.

Walker P.R., Saas P., Dietrich P.Y. 1997. Role of Fas ligand (CD95L) in immune escape: the tumor cell strikes back. J. Immunol. 158, 4521-4524.

Weller M., Fontana A. 1995. The failure of current immunotherapy for malignant glioma. Tumor-derived TGF-beta, T-cell apoptosis, and the immune privilege of the brain. Brain Res. Brain Res. Rev. 21, 128-151.

Weller M., Weinstock C., Will C., Wagenknecht B., Dichgans J., Lang F., Gulbins E. 1997. CD95-dependent T-cell killing by glioma cells expressing CD95 ligand: more on tumor immune escape, the CD95 counterattack, and the immune privilege of the brain. Cell. Physiol. Biochem. 7, 282-288.

Widner B., Werner E.R., Schennach H., Wachter H., Fuchs D. 1997. Simultaneous measurement of serum tryptophan and kynurenine by HPLC. Clin. Chem. 43, 2424-2426.

Wiendl H., Mitsdoerffer M., Hofmeister V., Wischhusen J., Bornemann A., Meyermann R., Weiss E.H., Melms A., Weller M. 2002. A functional role of HLA-G expression in human gliomas: an alternative strategy of immune escape. J. Immunol. 168, 4772-4780. 
Wilmotte R., Burkhardt K., Kindler V., Belkouch M.C., Dussex G., Tribolet N., Walker P.R., Dietrich P.Y. 2005. B7-homolog 1 expression by human glioma: a new mechanism of immune evasion. Neuroreport. 16, 1081-1085.

Wintterle S., Schreiner B., Mitsdoerffer M., Schneider D., Chen L., Meyermann R., Weller M., Wiendl H. 2003. Expression of the B7-related molecule B7-H1 by glioma cells: a potential mechanism of immune paralysis. Cancer Res. 63, 7462-7467.

Yamanaka R. 2008. Cell- and peptide-based immunotherapeutic approaches for glioma. Trends Mol. Med. 14, 228-235.

Yamanaka R., Abe T., Yajima N., Tsuchiya N., Homma J., Kobayashi T., Narita M., Takahashi M., Tanaka R. 2003. Vaccination of recurrent glioma patients with tumour lysatepulsed dendritic cells elicits immune responses: results of a clinical phase I/II trial. Br. J. Cancer. 89, 1172-1179.

Yamanaka R., Homma J., Yajima N., Tsuchiya N., Sano M., Kobayashi T., Yoshida S., Abe T., Narita M., Takahashi M., Tanaka R. 2005. Clinical evaluation of dendritic cell vaccination for patients with recurrent glioma: results of a clinical phase I/II trial. Clin. Cancer Res. 11, 4160-4167.

Yu J.S., Liu G., Ying H., Yong W.H., Black K.L., Wheeler C.J. 2004. Vaccination with tumor lysate-pulsed dendritic cells elicits antigen-specific, cytotoxic T-cells in patients with malignant glioma. Cancer Res. 64, 4973-4979. 
Zhang J.G., Eguchi J., Kruse C.A., Gomez G.G., Fakhrai H., Schroter S., Ma W., Hoa N., Minev B., Delgado C., Wepsic H.T., Okada H., Jadus M.R. 2007. Antigenic profiling of glioma cells to generate allogeneic vaccines or dendritic cell-based therapeutics. Clin. Cancer Res. 13, 566-575. 


\section{ACKNOWLEDGMENTS}

We thank persons and organizations which have contributed to this work: Stéphane Moiteaux for his excellent technical assistance; L. Amiot, V. Catros and A. Clavreul for their kind gifts of the JEG-3 trophoblastic cell line, U251 and U87MG cell lines, respectively; the Biogenouest ${ }^{\circledR}$ transcriptomic platform from Rennes for the microarray analysis; Alain Feutrel and Pascale Bellaud from the Biogenouest ${ }^{\circledR}$ histopathology platform (IFR 140, Université de Rennes 1) for the immunohistochemistry analysis on GBM specimens; Gwénaële Duval and Elodie Morilland for their help in RT-PCR experiments and HLA-G study, respectively; Michèle Marty for their help in Q-PCR experiments; Brigitte Collet for the Melan-A expression data of GBM specimens; the 'SITI-TC' unit of CHU Pontchaillou and Olivier Tribut for the evaluation of IDO activity. M.S.N. Carpenter post-edited the English style. 
Table 1: Primers used in the RT-PCR experiments*

\begin{tabular}{|c|c|c|}
\hline $\begin{array}{l}\text { Target } \\
\text { gene }\end{array}$ & Primer sequence & $\begin{array}{l}\text { Expected size of the } \\
\text { PCR-amplified fragment }\end{array}$ \\
\hline$\beta$-actin & $\begin{array}{l}\text { S: 5'-AGAGATGGCCACGGCTGCTT-3' } \\
\text { AS: 5'-ATTTGCGGTGGACGATGGAG-3' }\end{array}$ & $653 \mathrm{bp}$ \\
\hline FasL & $\begin{array}{l}\text { S: 5'-GTGCCCAGAAGGCCTGGTCAAAGG-3' } \\
\text { AS: 5'-TTGCAAGATTGACCCCGGAAGTAT-3' }\end{array}$ & 503 bp \\
\hline HLA-G & $\begin{array}{l}\text { S: 5'-CGGAGTATTGGGAAGAGGAG-3' } \\
\text { AS: 5'-TACAGCTGCAAGGACAACCA-3' }\end{array}$ & $\begin{array}{l}722 \text { bp for HLA-G1 } \\
446 \text { bp for HLA-G2 and -G4 } \\
170 \text { bp for HLA-G3 } \\
844 \text { bp for HLA-G5 } \\
568 \text { bp for HLA-G6 }\end{array}$ \\
\hline IDO & $\begin{array}{l}\text { S: 5'-ACAGACCACAAGTCACAGCG-3' } \\
\text { AS: 5'-AACTGAGCAGCATGTCCTCC-3' }\end{array}$ & $662 \mathrm{bp}$ \\
\hline PDL-1 & $\begin{array}{l}\text { S: 5'-GACCTATATGTGGTAGAGTATGGTAGC-3' } \\
\text { AS: 5'-TTCAGCTGTATGGTTTTCCTCAGGATC-3' }\end{array}$ & 594 bp \\
\hline TGF- $\beta 1$ & $\begin{array}{l}\text { S: 5'-GCGGTACCTGAACCCGTGTT-3' } \\
\text { AS: 5'-GTCAATGTACAGCTGCCGCAC-3' }\end{array}$ & $477 \mathrm{bp}$ \\
\hline TGF- $\beta 2$ & $\begin{array}{l}\text { S: 5'-CCGGAGGTGATTTCCATCTA-3' } \\
\text { AS: 5'-CTCCATTGCTGAGACGTCAA-3' }\end{array}$ & $219 \mathrm{bp}$ \\
\hline TGF- $\beta 3$ & $\begin{array}{l}\text { S: 5'-CTCTCTGTCCACTTGCACCA-3' } \\
\text { AS: 5'-ACACATTGAAGCGGAAAACC-3' }\end{array}$ & $344 \mathrm{bp}$ \\
\hline
\end{tabular}

* S: sense primer; AS: anti-sense primer. 
Table 2: IDO protein expression on GBM cell lines*

\begin{tabular}{ccc}
\hline GBM cell lines & untreated & IFN-y-treated \\
\hline GBM \#1 & + & +++ \\
GBM \#2 & $-/+$ & +++ \\
GBM \#3 & + & +++ \\
GBM \#4 & ++ & +++ \\
GBM \#5 & + & +++ \\
GBM \#6 & + & +++ \\
GBM \#7 & $-/+$ & +++ \\
GBM \#8 & + & +++ \\
GBM \#9 & $-/+$ & +++ \\
GBM \#10 & $-/+$ & +++ \\
U251 & $-/+$ & +++ \\
U87MG & $-/+$ & +++ \\
\hline
\end{tabular}

* Protein expression was analysed by immunohistochemistry on 10 GBM primary cell lines, U251 and U87MG after staining with specific antibodies against IDO. Results are expressed as percentage of positive tumour cells, as described in Materials and Methods. -: negative; -/+: $1-25 \%$; +: $26-50 \%$; ++: $51-75 \%$; and +++: $76-100 \%$ of analysed cells. 
Table 3: IDO and PDL-1 protein expression on GBM specimens*

\begin{tabular}{ccc}
\hline $\begin{array}{c}\text { GBM } \\
\text { samples }\end{array}$ & $\begin{array}{c}\text { IDO } \\
\text { staining }\end{array}$ & $\begin{array}{c}\text { PDL-1 } \\
\text { staining }\end{array}$ \\
\hline & & \\
$\# 1$ & +++ & ++ \\
$\# 2$ & +++ & +++ \\
$\# 3$ & ++ & $-/+$ \\
$\# 4$ & +++ & + \\
$\# 5$ & +++ & $-/+$ \\
$\# 6$ & ++ & $-/+$ \\
$\# 7$ & +++ & $-/+$ \\
$\# 8$ & ++ & $-/+$ \\
$\# 9$ & +++ & $-/+$ \\
$\# 10$ & +++ & $-/+$ \\
$\# 11$ & +++ & $-/+$ \\
$\# 12$ & +++ & +++ \\
$\# 13$ & +++ & +++ \\
$\# 14$ & +++ & $-/+$ \\
$\# 15$ & +++ & + \\
$\# 16$ & ++ & $-/+$ \\
$\# 17$ & +++ & + \\
$\# 18$ & +++ & + \\
$\# 19$ & ++ & $-/+$ \\
$\# 20$ & +++ & + \\
& & \\
\hline & &
\end{tabular}

* Protein expression was analysed by immunohistochemistry on 20 GBM samples after staining of the tumour sections with specific antibodies against IDO and PDL-1. GBM specimens are unrelated to specimens used to generate GBM primary cell lines. Results are expressed as percentage of positive tumour cells as described in Materials and Methods. -: negative; -/+: 1-25\%; +: 26-50\%; ++: 51-75\%; and +++: 76$100 \%$ of analysed cells. 


\section{FIGURE LEGENDS}

Figure 1: FasL, HLA-G, IDO, PDL-1 and TGF- $\beta 1-3$ mRNA expression on 20 GBM samples by transcriptomic microarray analysis.

Total mRNA from 20 GBM samples was extracted and analysed for a gene expression profile as described in (de Tayrac et al., 2009). Results are expressed as the relative mRNA expression compared to a pool of non-neoplastic brain samples. Samples are considered as positive when relative mRNA expression shows more than a two-fold increase (solid line) compared to the reference.

Figure 2: FasL, HLA-G, IDO, PDL-1 and TGF- $\beta 1-3$ mRNA expression on GBM cell lines by $R T-P C R$

Total mRNA from untreated (A) or IFN- $\gamma$-treated (B) GBM primary cell lines, U251 and U87MG was extracted, reverse transcribed and then amplified with specific primers for $\beta$ actin, FasL, HLA-G, IDO, PDL-1 and TGF- $\beta 1-3$ molecules. Positive controls were used: JURKAT cell line for FasL and $\beta$-actin, JEG-3 cell line for $H L A$ - $G$, IFN- $\gamma$-treated monocytes for $I D O$ and $P D L-1$, and MCF-7 cell line for $T G F-\beta 1-3$. Amplified products were analysed by electrophoresis in $2 \%$ agarose gel and migrated at the position corresponding to their expected size.

Figure 3: HLA class I, HLA-G and PDL-1 protein expression on GBM cell lines.

Untreated (shaded histograms) or IFN- $\gamma$-treated GBM cell lines, U251 and U87MG (open histograms with thick lines) were stained with isotype controls (open histograms with thin 
lines) or specific labelled antibodies against HLA class I, HLA-G and PDL-1 molecules, and then analysed by flow cytometry. JEG-3 cell line and IFN- $\gamma$-treated monocytes were used as positive controls for HLA-G and PDL-1 expression, respectively. Values in the top-right corners (in bold for IFN- $\gamma$-treated cells) indicate the mean of specific fluorescence intensity of the protein expression determined in at less three different experiments as described in Materials and Methods.

Figure 4: IDO protein expression, IDO activity and TGF- $\beta 2$ secretion on GBM cell lines.

(A): Untreated or IFN- $\gamma$-treated GBM cell lines were stained with specific anti-IDO antibodies and analysed by immunohistochemistry as described in Materials and Methods. Sections of human placenta, as positive controls, were stained with an isotype control and anti-IDO antibodies. A representative primary cell line GBM\#2 is shown. (B and C): Untreated ( $\square$ ) or IFN- $\gamma$-treated ( $\square$ ) GBM cell lines, U251 and U87MG were cultured for 48 hours in fresh medium. Supernatants were then collected and analysed for IDO activity (B) and TGF- $\beta 2$ secretion (C). Levels of tryptophan and kynurenin were assessed by HPLC and IDO activity was determined by the ratio kynurenin / tryptophan. Supernatants of untreated and IFN- $\gamma$-treated monocytes were used as controls (B). TGF- $\beta 2$ secretion was performed by ELISA after acidification of the supernatants (C). Results are representative of results obtained in three independent experiments.

Figure 5: Role of IDO, PDL-1 and TGF- $\beta 1-3$ on IFN- $\gamma$ production and cell cytotoxicity of Melan-A/HLA-A2-specific T cells against Melan-A-loaded GBM cell lines. 
Melan-A/HLA-A2-specific $\mathrm{T}$ cell lines were generated in vitro after co-culture with autologous dendritic cells loaded with Melan-A peptides. (A): Melan-A/HLA-A2-specific T cell lines obtained were stained with Melan-A/HLA-A2 tetramers and anti-CD8 antibodies, and then analysed by flow cytometry. (B): Melan-A/HLA-A2-specific T cell lines were incubated with unloaded or Melan-A-loaded HLA-A2 expressing T2 cells (used as controls) and untreated ( $\square$ ) or IFN- $\gamma$-treated ( $\square$ ) GBM cell lines for 24 hours. Supernatants were then collected and analysed for IFN- $\gamma$ production by ELISA. (C): Melan-A/HLA-A2-specific T cell lines were used as effectors in a 4 hours cell cytotoxicity assay against ${ }^{51} \mathrm{Cr}$-labelled unloaded ( $\square$ ) or Melan-A-loaded ( $\square$ ) T2 cells, untreated ( $\square$ ) and IFN- $\gamma$-treated ( $\square$ ) GBM cell lines. Different effector : target (E:T) ratios were used and specific lysis was calculated as indicated in Materials and Methods. Melan-A/HLA-A2-specific T cell lines were used as effectors in a 24-hr IFN- $\gamma$ production (D) and 4-hr cell cytotoxicity assays (E) in the presence or not $(\square)$ of blocking antibodies against PDL-1 ( $\square$ ); TGF- $\beta 1-3$ (N) or in the presence of 1methyl tryptophan (ם), an IDO inhibitor. Melan-A-loaded T2, untreated and IFN- $\gamma$-treated GBM cell lines were used as target cells. Results are representative of results obtained with three different Melan-A/HLA-A2-specific T cell lines. $\left.{ }^{*}\right) \mathrm{p}<0.05$.

Figure 6: Role of IDO on PHA-induced PBMC proliferation.

PBMC were cultured for 3 days with PHA and irradiated T2 cells (used as a control), untreated or IFN- $\gamma$-treated GBM cell lines in the presence or not ( $\square$ ) of 1-methyl tryptophan (匹). ${ }^{3} \mathrm{H}$-thymidine was added 18 hours before the end of the assay and cell incorporation of ${ }^{3} \mathrm{H}$-thymidine, corresponding to the PBMC proliferation, was determined as described in Materials and Methods. $(*) \mathrm{p}<0.05$. 
Figure 7: IDO and PDL-1 $\mathrm{mRNA}$ and protein expression in a series of 20 GBM samples.

(A): mRNA from a series of $20 \mathrm{GBM}$ specimens was isolated and analysed by Q-PCR for IDO and PDL-1 mRNA expression. Results are expressed as the relative mRNA expression compared to a pool of non-neoplastic brain samples. The solid line indicates the 5-fold increase in mRNA expression compared to the reference. (B): GBM samples were stained with specific anti-IDO or anti-PDL-1 antibodies and analysed by immunohistochemistry. Placenta and urothelial carcinoma sections were used as positive controls for IDO and PDL-1, respectively. Two representative GBM specimens are shown. (C): The correlation curves between RNA expression and protein expression are calculated for IDO and PDL-1 molecules. $\mathrm{R}^{2}$ indicates the correlation coefficient. 
Figure 1

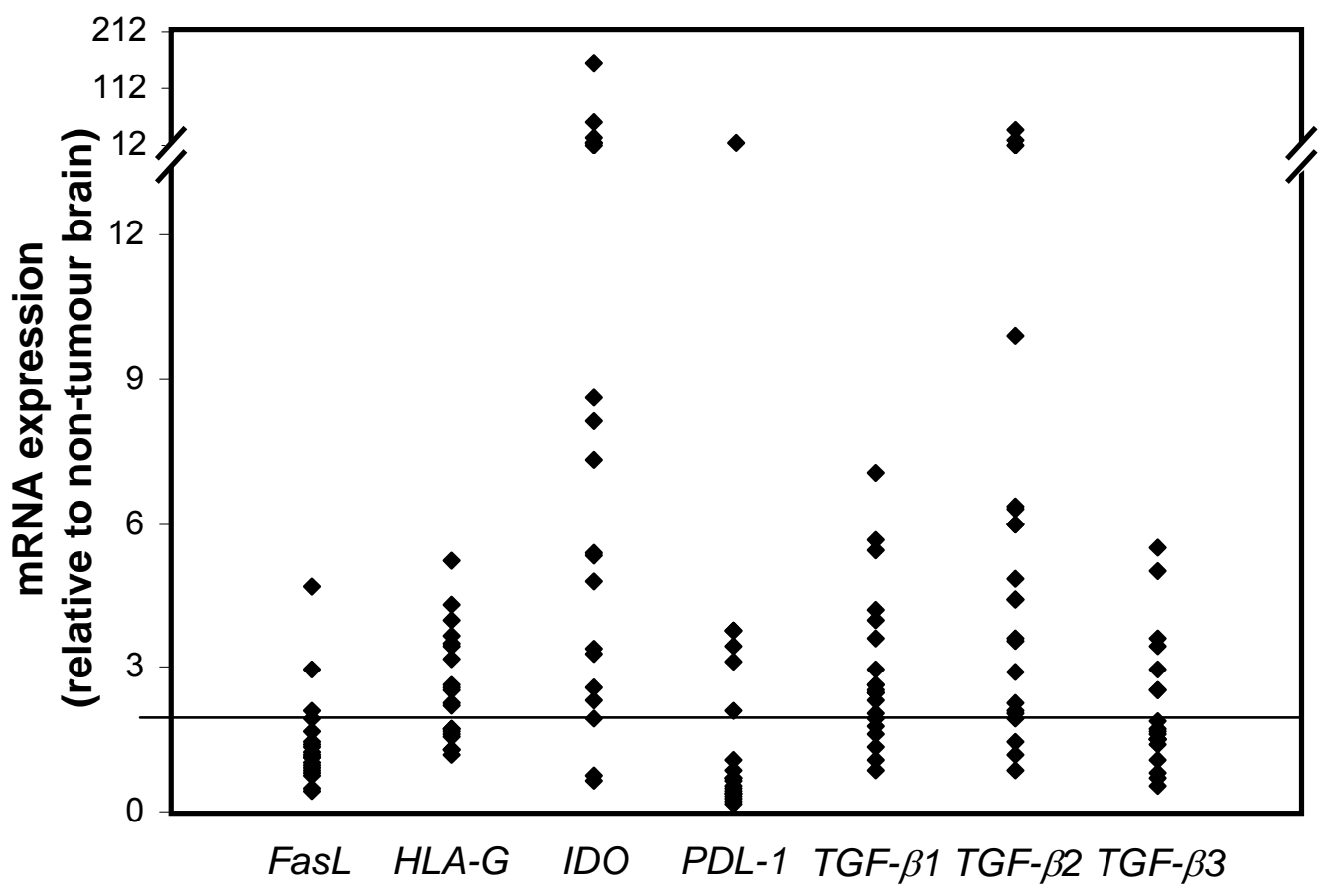


Figure 2

A: untreated cells

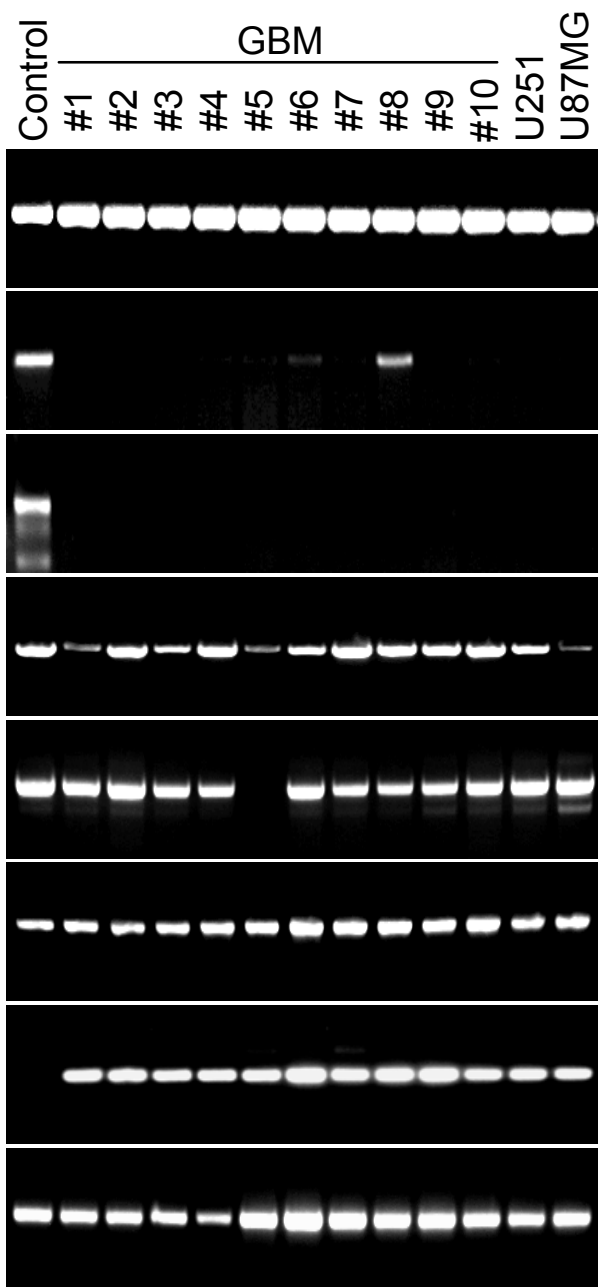

B: IFN- $\gamma$-treated cells

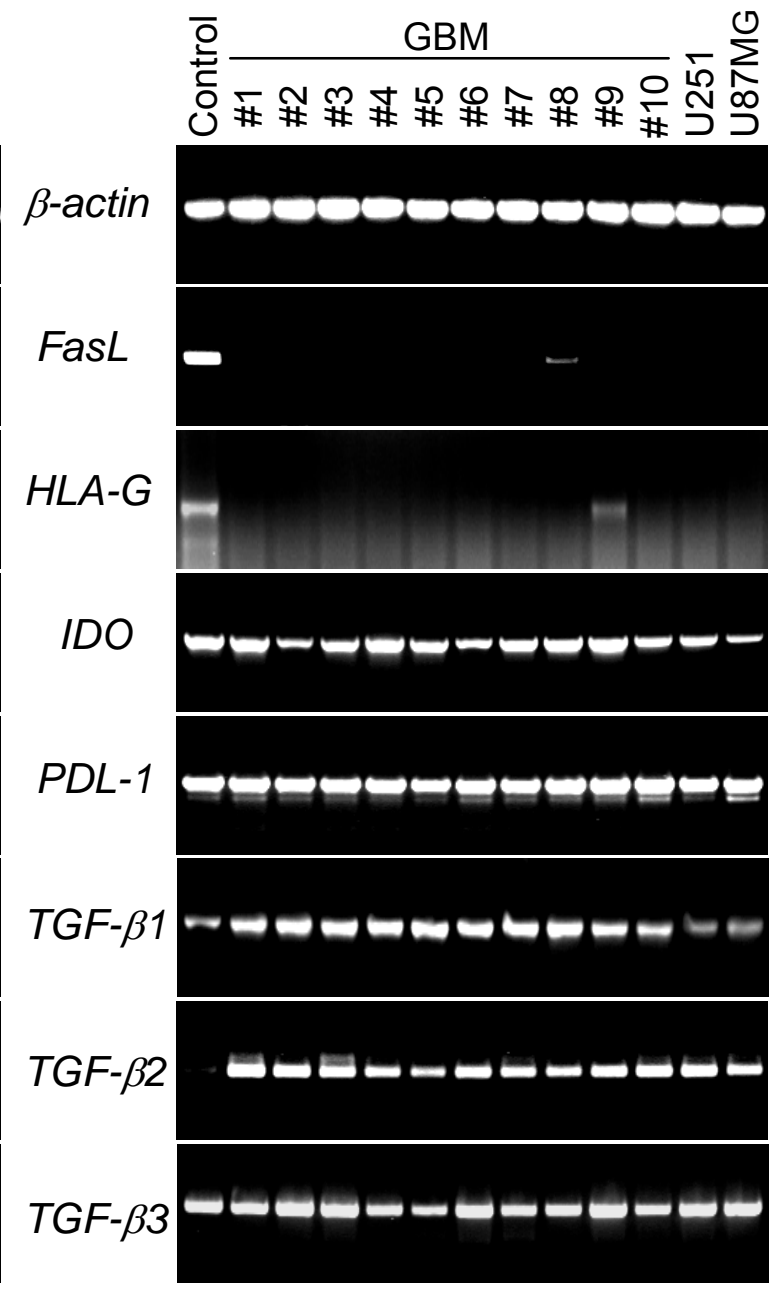


Figure 3

HLA-ABC HLA-G PDL-1

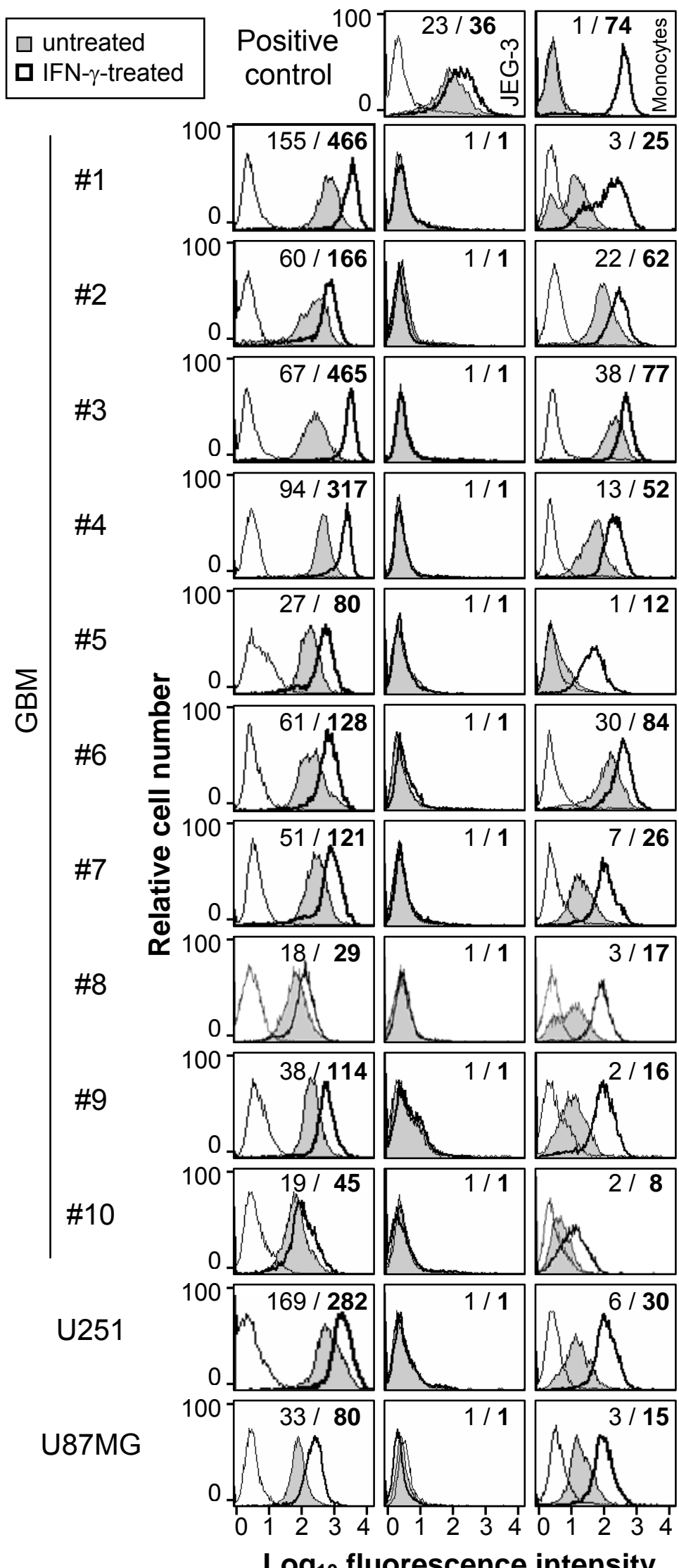

$\log _{10}$ fluorescence intensity 
Figure 4

A: IDO

B: IDO

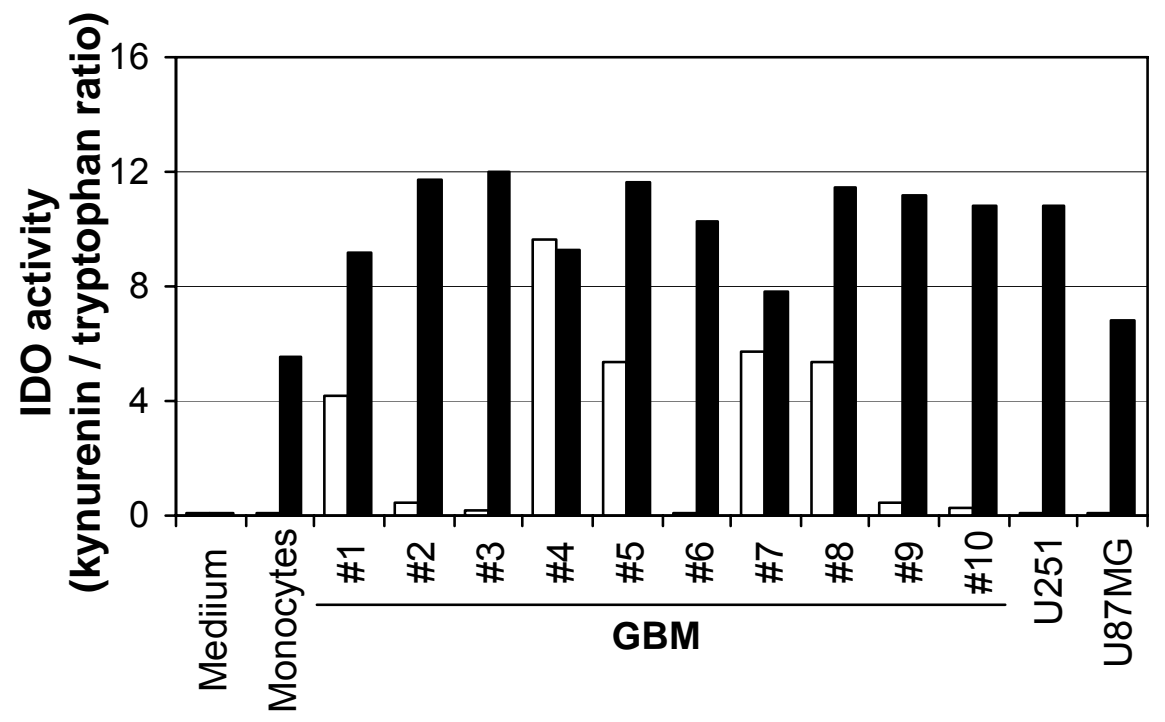

C: TGF-ß2

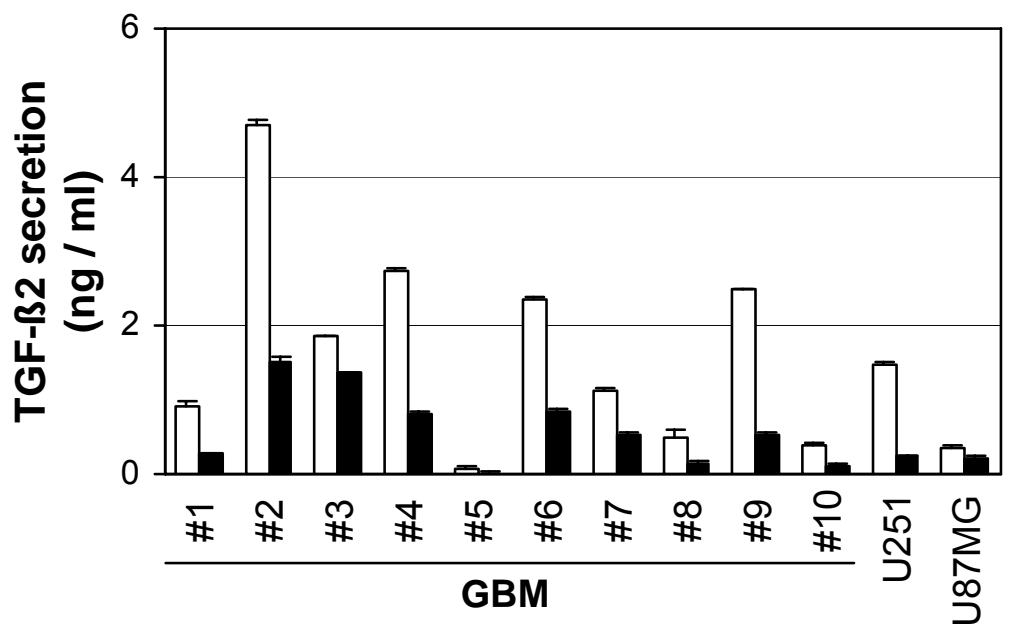


Figure 5

A

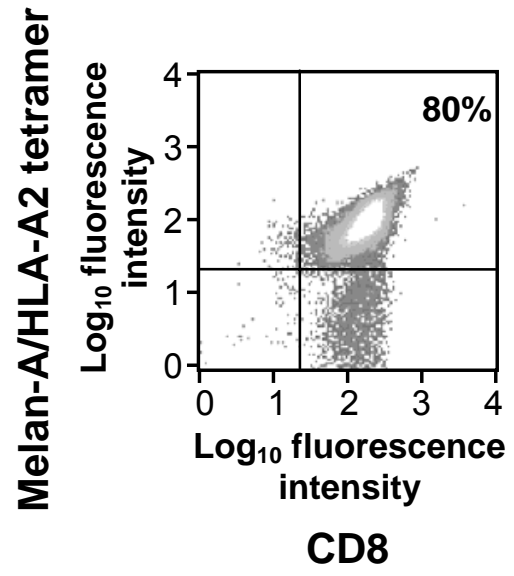

D

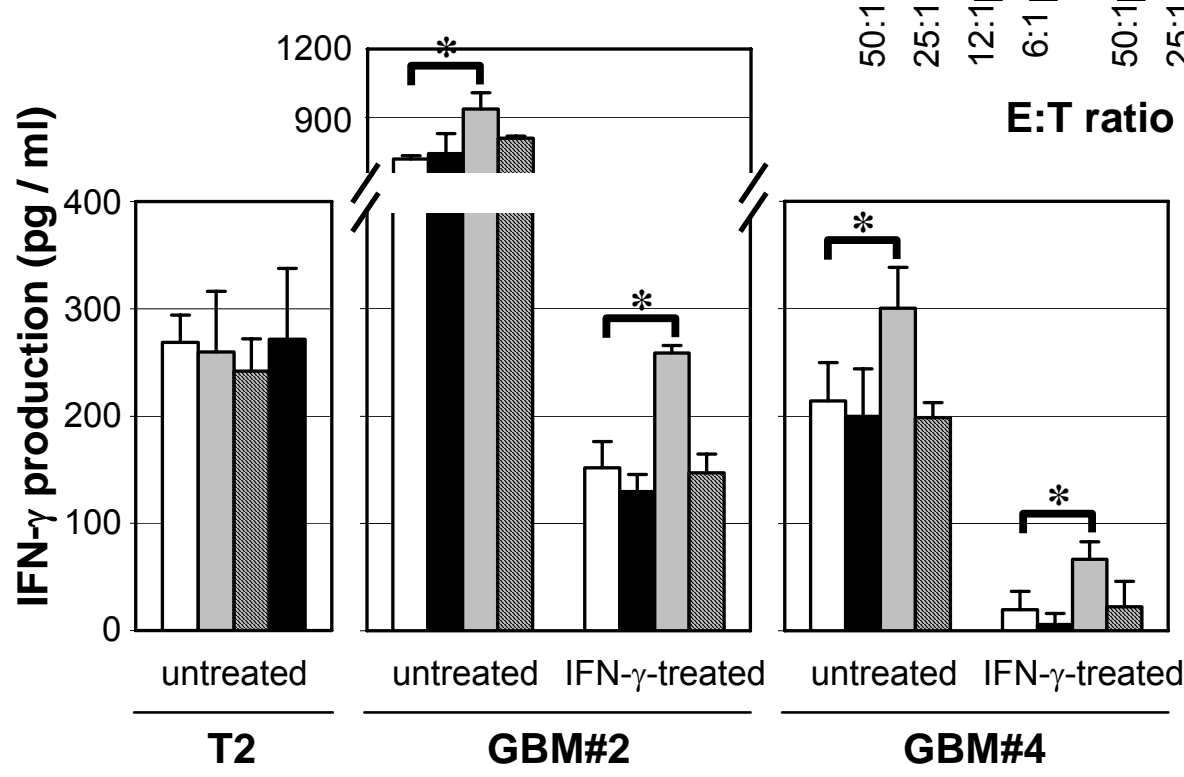

E

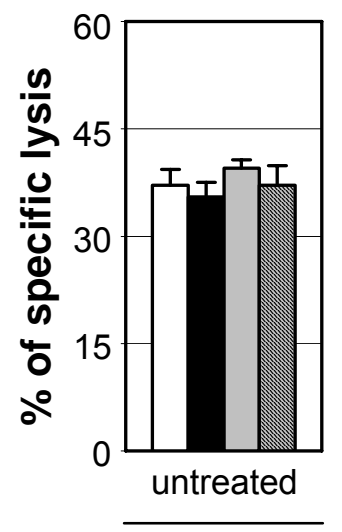

T2

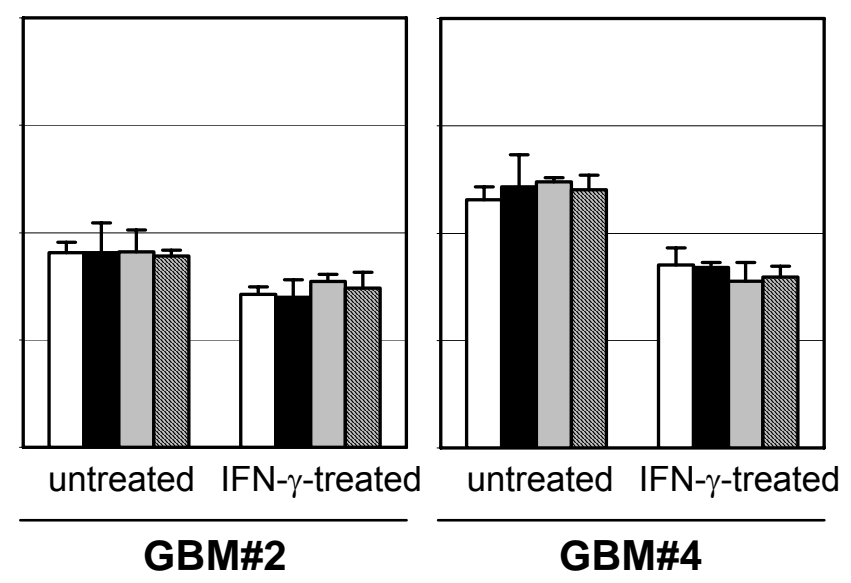

B

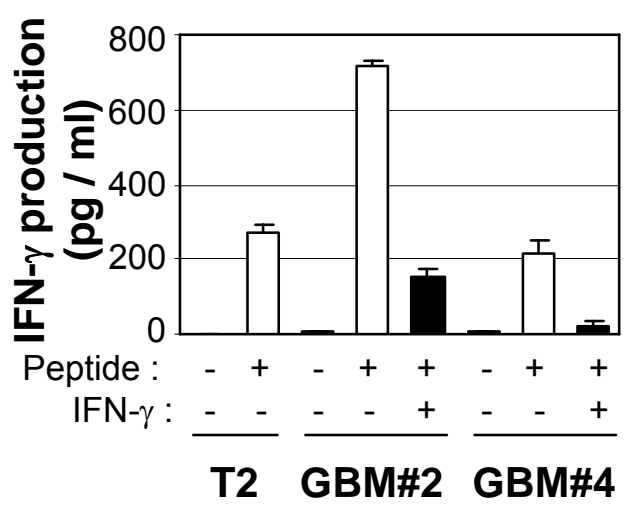

C

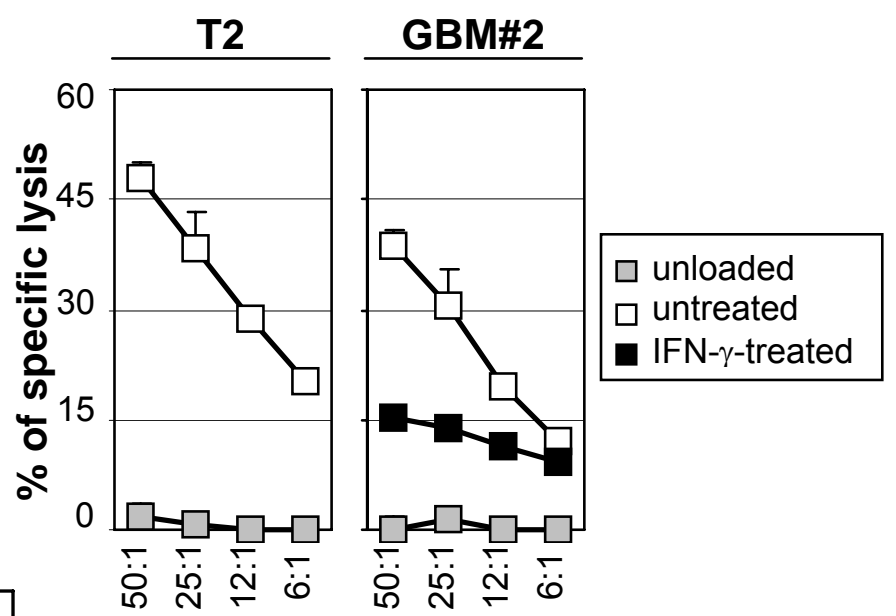

$\square$ alone

- 1-MT

$\square$ anti-PDL-1

$\mathbf{v}$ anti-TGF-ß1-3

$\square$ alone

- 1-MT

$\square$ anti-PDL-1

$\mathbf{v}$ anti-TGF-ß1-3 
Figure 6

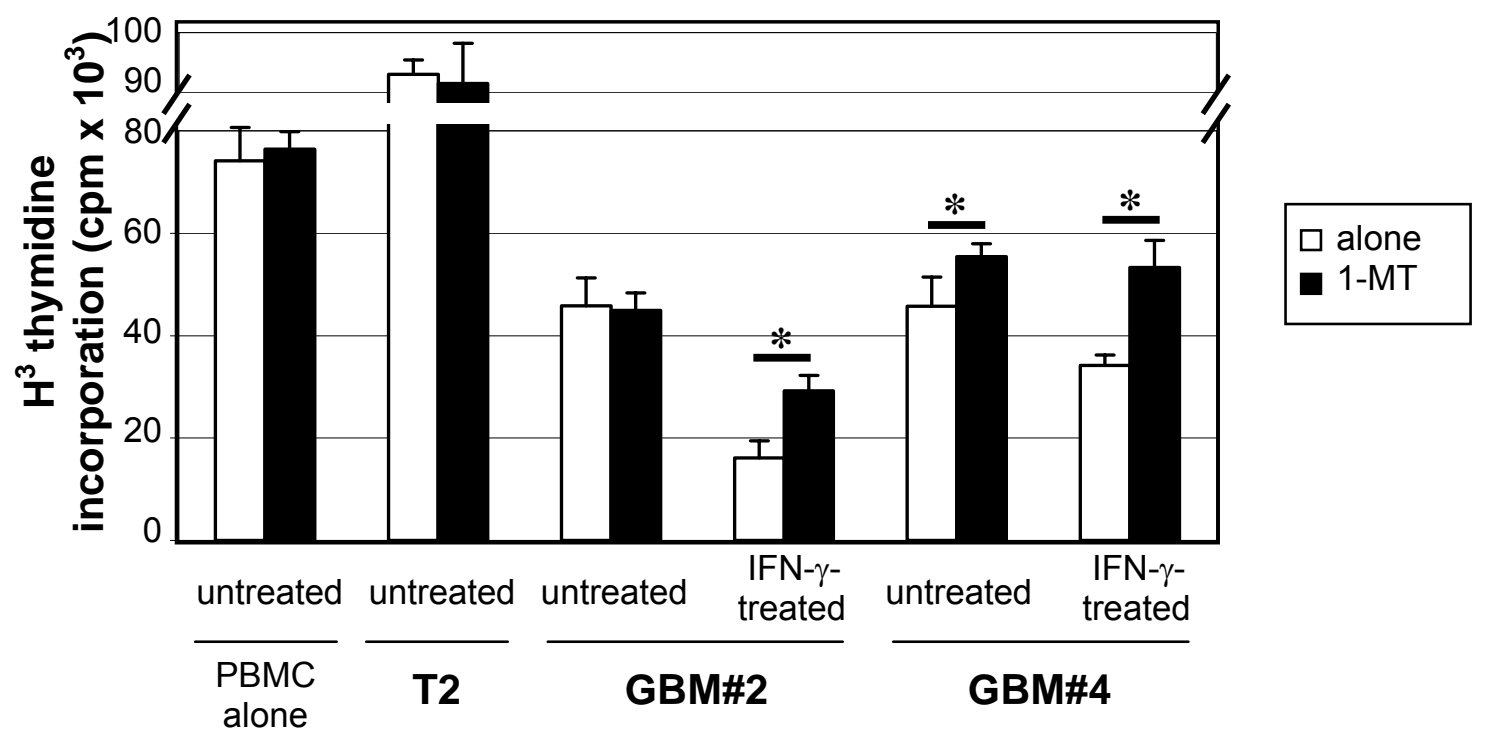


Figure 7

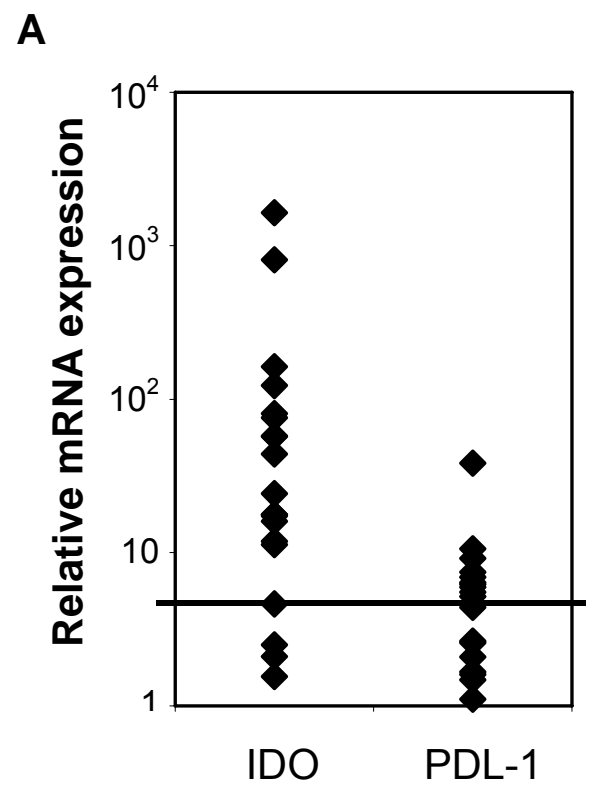

B

IDO
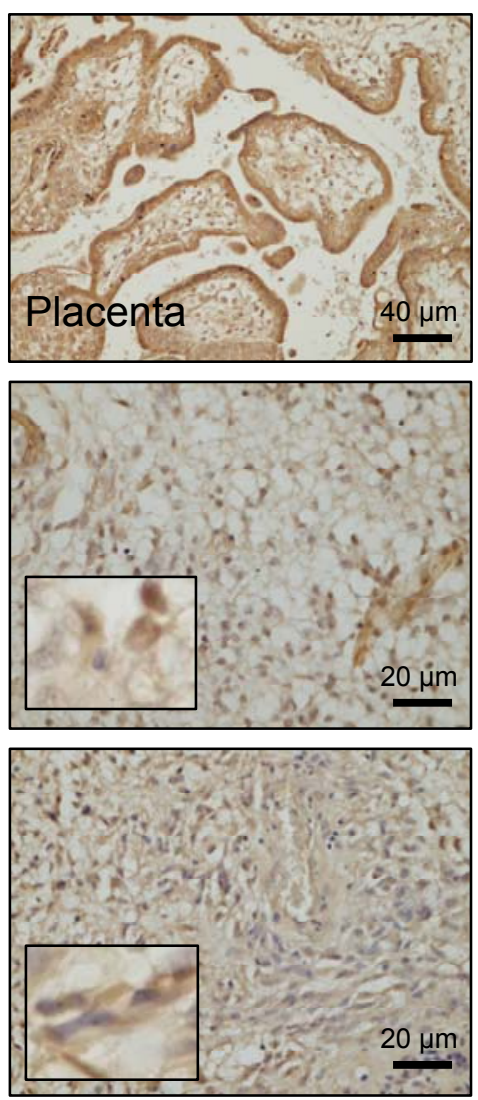

PDL-1
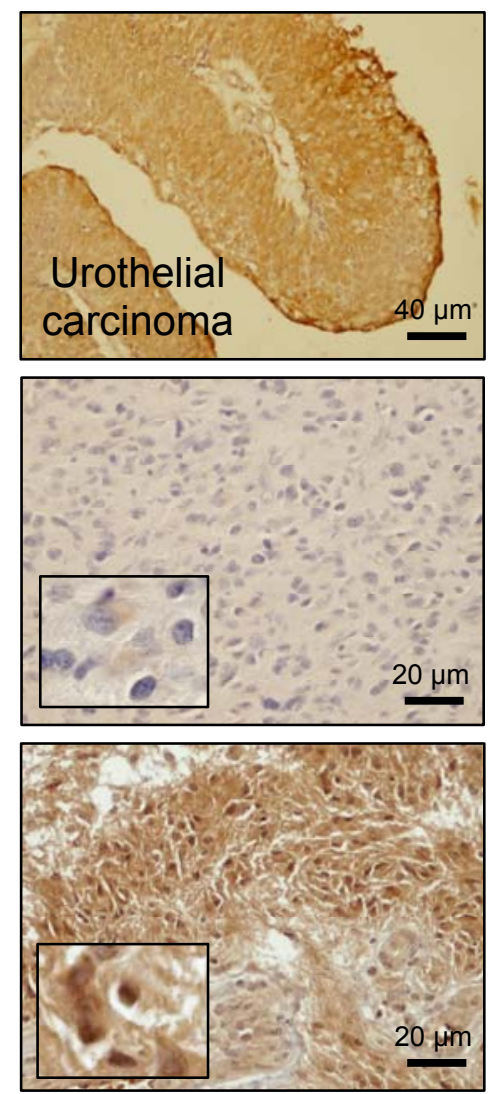

Positive control

Sample \#6

Sample \#13

C

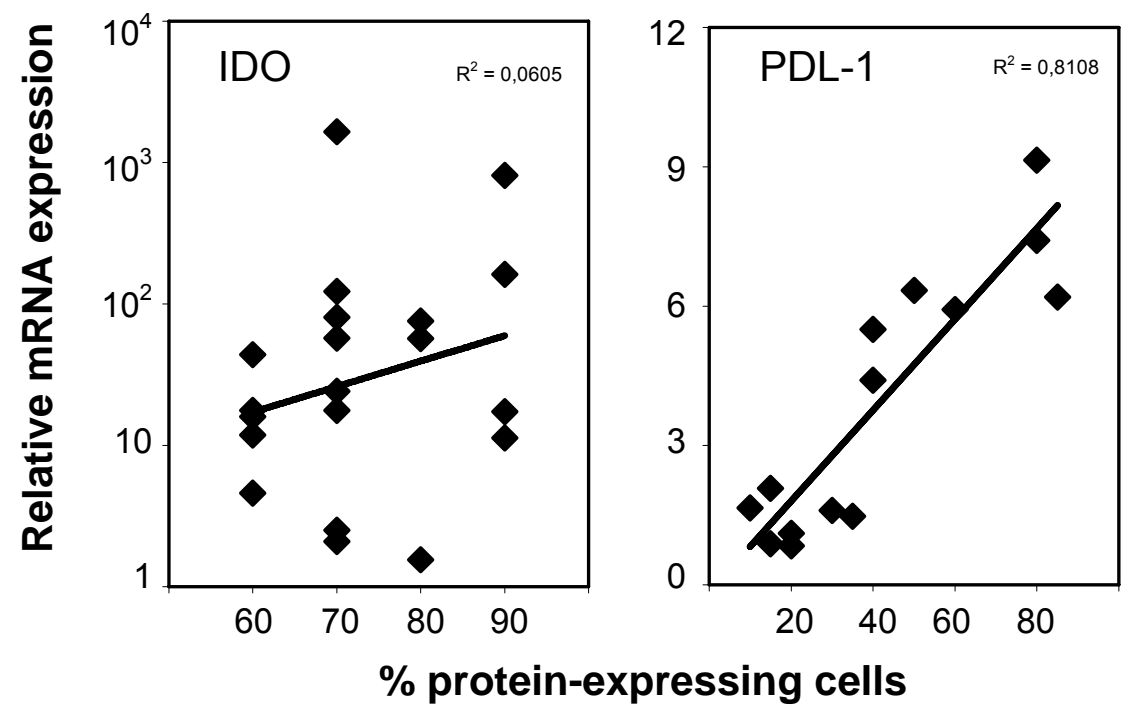




\section{SUPPLEMENTARY DATA}

\section{Materials and methods}

GBM cell lines supernatants.

Cells were grown in culture medium for 48 hours in the presence or not of $1000 \mathrm{U}$ per $\mathrm{ml}$ of IFN- $\gamma$. Cells were then washed and incubated in culture medium for 24 hours at a concentration of $1 \times 10^{6}$ cells per ml. Supernatants were then centrifuged at $400 \mathrm{~g}$ for $5 \mathrm{~min}$ and used in the IFN- $\gamma$ release assay. For blocking experiments, supernatants were incubated with

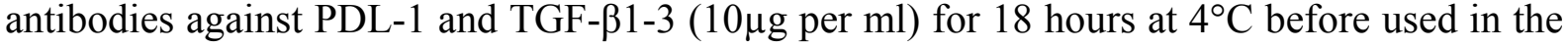
IFN- $\gamma$ secretion assay.

IFN- $\gamma$ release assay.

Irradiated HLA-A2 expressing T2 target cells were washed and plated in RPMI 10\% FCS at a concentration of $1 \times 10^{4}$ per well in a 96U-well microplate. Melan-A/HLA-A2-specific T cell lines used as effector cells were washed and added to the target cells at $5 \times 10^{4}$ cells per well. Supernatants obtained from untreated or IFN- $\gamma$-treated GBM cell lines were added at 3:4 dilution. Cells were incubated for 24 hours at $37^{\circ} \mathrm{C}$ at the final volume of $200 \mu 1$ per well. At the end of the assay, $150 \mu 1$ of supernatant were centrifuged and analysed for IFN- $\gamma$ by ELISA.

\section{Figure legends}

Figure S1: Expression of vimentin and tumour antigens by GBM primary cell lines.

10 GBM primary cell lines were generated from GBM samples and characterised by their expression of vimentin (A) and tumour antigens IL13R $\alpha 2$, EGFRvIII and gp100 (B). Vimentin expression was performed by immunohistochemistry. Tumour antigen expression was analysed by flow cytometry after staining with specific labelled antibodies. For gp100 expression, cells were fixed and permeabilised before the staining. Values in the top-right corners indicate the mean of specific fluorescence intensity of the tumour antigens tested determined in at less three different experiments as described in Materials and Methods. GBM cell lines were considered as positive when the specific fluorescence intensity was more than two.

Figure S2: Role of PDL-1 and TGF- $\beta 1-3$ on IFN- $\gamma$ production of Melan-A/HLA-A2-specific T cells against Melan-A-loaded T2 cell lines in the presence of untreated or IFN- $\gamma$-treated GBM cell lines supernatants.

Melan-A/HLA-A2-specific T cell lines were incubated with unloaded or Melan-A-loaded HLA-A2 expressing T2 cells for 24 hours in the presence of supernatants obtained from untreated or IFN- $\gamma$-treated GBM cell lines $(\square)$. Blocking antibodies against PDL-1 ( $\square$ ); TGF$\beta 1-3$ ( $\mathbb{*}$ ) were added 18 hours to the supernatants and left during the assay. (**) $p<0.01$. 
Figure S1

A
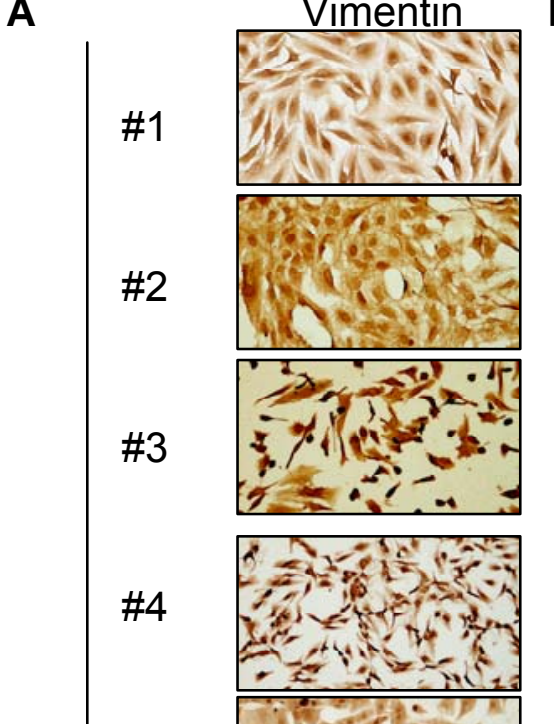

$\sum_{\substack{0 \\ 0}}$

\#5

\#6

\#7

\#8

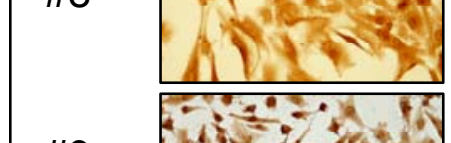

\#9

\#10

U251

U87MG

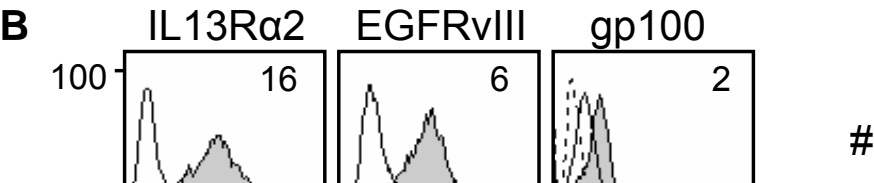

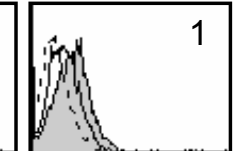

\#2

\#3

\#4

\#5

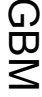

\#6

\#7
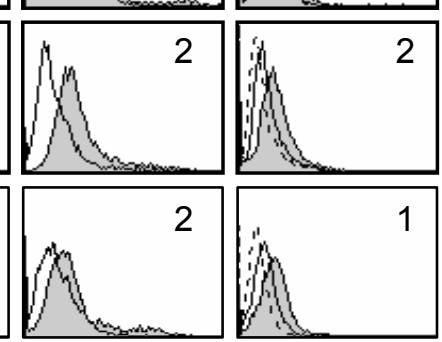

\#8

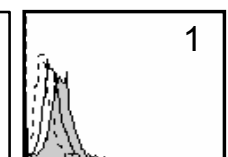

\#9

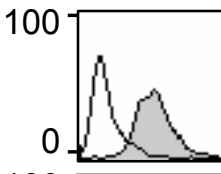

100
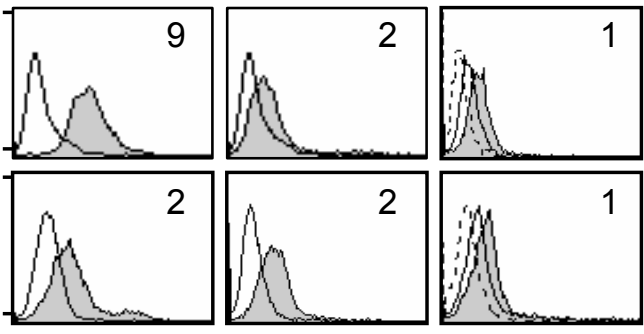

\#10

100
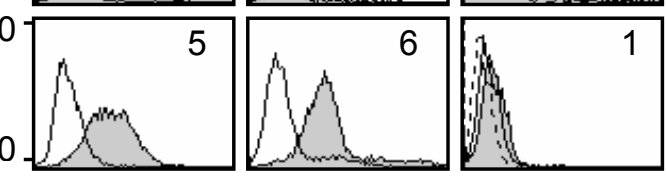

U251

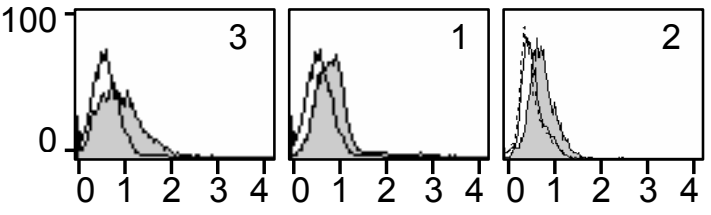

U87MG

\section{$\log _{10}$ fluorescence intensity}


Figure S2

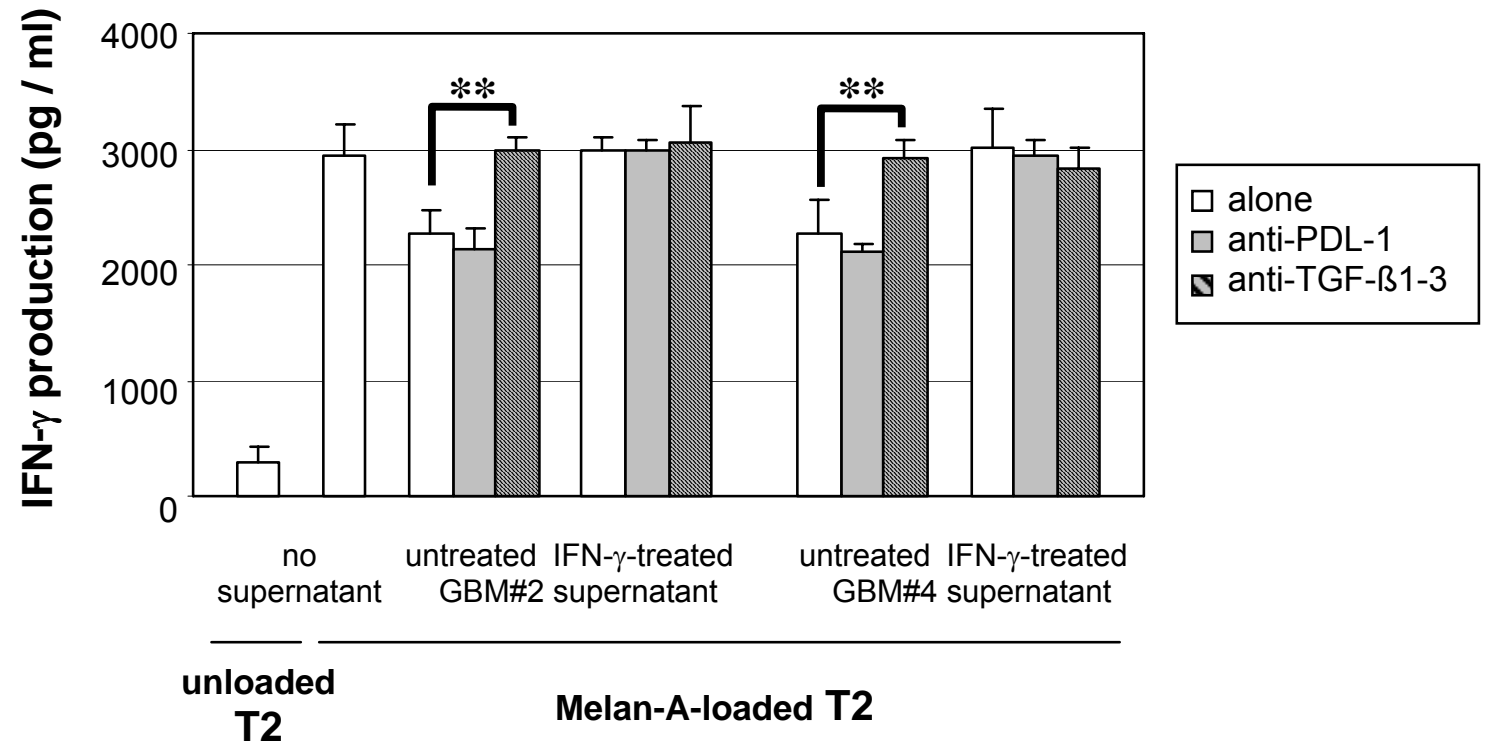

